\title{
Trigger and Suppression of Antiviral Defenses by Grapevine Pinot Gris Virus (GPGV): Novel Insights into Virus-Host Interaction
}

\author{
Giulia Tarquini, ${ }^{\dagger}$ Laura Pagliari, Paolo Ermacora, Rita Musetti, and Giuseppe Firrao \\ Department of Agriculture, Food, Environmental and Animal Sciences, University of Udine, Udine I-33100, Italy \\ Accepted 12 May 2021.
}

\begin{abstract}
Grapevine Pinot gris virus (GPGV) is an emerging trichovirus that has been putatively associated with a novel grapevine disease known as grapevine leaf mottling and deformation (GLMD). Yet the role of GPGV in GLMD disease is poorly understood, since it has been detected both in symptomatic and symptomless grapevines. We exploited a recently constructed GPGV infectious clone (pRI::GPGV-vir) to induce an antiviral response in Nicotiana benthamiana plants. In silico prediction of virus-derived small interfering RNAs and gene expression analyses revealed the involvement of DCL4, AGO5, and RDR6 genes during GPGV infection, suggesting the activation of the posttranscriptional gene-silencing (PTGS) pathway as a plant antiviral defense. PTGS suppression assays in transgenic $N$. benthamiana $16 \mathrm{c}$ plants revealed the ability of the GPGV coat protein to suppress RNA silencing. This work provides novel insights on the interaction between GPGV and its host, revealing the ability of the virus to trigger and suppress antiviral RNA silencing.
\end{abstract}

Keywords: GPGV, GLMD, RNA silencing, grapevine, silencing suppressor, stem-loop RT-PCR

Vitis vinifera is the world's most commercially and socially relevant fruit crop, standing out among cultivated plant species for its paramount economic relevance (Keller 2015). Grapevines can be subject to attacks by many different pests and pathogens, including graft-transmissible agents such as viruses, viroids, and phytoplasmas (Meng et al. 2017). Viral diseases are major issues in viticulture, since grapevines can be infected with more than 80 different viruses that alter plant metabolism, causing significant losses in yield and fruit quality (Martelli 2017; Oliver and Fuchs 2011). The association of specific symptoms with particular viruses is a hard task due to the occurrence of mixed infections and to the presence of infected grapevines that appear completely symptomless (Oliver and Fuchs 2011).

A novel trichovirus, named grapevine Pinot gris virus (GPGV), was recently discovered in northeast Italy (Giampetruzzi et al. 2012). The virus has been putatively associated with an emerging disease, known as grapevine leaf mottling and deformation

${ }^{\dagger}$ Corresponding author: G. Tarquini; giulia.tarquini@uniud.it

Funding: The research was carried out with the authors' own funds.

The author(s) declare no conflict of interest.

(c) (1) () $\odot$ Copyright $\odot 2021$ The Author(s). This is an open access article (c) ${ }_{\text {BY NC ND }}$ distributed under the CC BY-NC-ND 4.0 International license.
(GLMD), which was first reported in vineyards in northeast Italy and more recently worldwide (Tarquini et al. 2018). Symptoms associated with GPGV infection, including leaf mottling and deformation, short internodes, stunted shoots, and reduced yield, are more distinct at the beginning of the vegetative season, while they tend to be attenuated on late season growth (Bertazzon et al. 2017; Bianchi et al. 2015). A large number of cases of asymptomatic grapevines hosting GPGV from June onward has also been reported (Bertazzon et al. 2017; Bianchi et al. 2015; Giampetruzzi et al. 2012; Saldarelli et al. 2015; Tarquini et al. 2018).

Several studies have been performed to clarify the ambiguous association between the presence of GPGV and the expression of GLMD symptoms (Bertazzon et al. 2017; Buoso et al. 2020; Hily et al. 2020; Saldarelli et al. 2015; Tarquini et al. 2019a and $b$ ). However, a convincing explanation of the phenomenon has not been provided yet.

A major step forward was provided by demonstrating that both a virulent (pRI::GPGV-vir) and a latent (pRI::GPGV-lat) infectious clone of the virus were able to elicit GLMD symptoms in diverse plant species, such as Nicotiana benthamiana and $V$. vinifera (Tarquini et al. 2019a and b). Interestingly, the study also revealed that the trend of symptoms in agroinoculated grapevines perfectly matched symptom progression in naturally infected grapevine plants in the field (Bertazzon et al. 2017; Bianchi et al. 2015), disappearing in about three weeks (i.e., 4 months post inoculum) and occurring again on emerging young leaves at later stages of infection (Tarquini et al. 2019a and b).

In this study, the GPGV infectious clones developed by Tarquini et al. (2019a and b) were further exploited to study the antiviral defense mechanism or mechanisms activated by plants in response to GPGV infection.

Among the network of interactions triggered in plants against viruses, RNA silencing-based responses have a great impact on antiviral immunity (Ratcliff et al. 1999; Waterhouse et al. 2001). Antiviral RNA silencing relies on the production of virusderived small interfering RNAs (vsiRNAs) that mediate cleavage or translational inhibition of the complementary viral genome (Csorba and Burgyán 2016; Voinnet 2001, 2008).

The long double-stranded RNAs (dsRNAs) produced as intermediates of virus replication (Fire 1999; Meister and Tuschl 2004) are processed, by RNAse-III type enzymes called Dicerlike proteins (DCLs), into primary vsiRNAs (Bernstein et al. 2001; Henderson et al. 2006; Liu et al. 2009), which are incorporated into Argonaute (AGO) protein by activating the RNAinduced silencing complex, which, in turn, mediates cleavage or translational suppression of the cognate viral RNAs (Carbonell and Carrington 2015; Czech and Hannon 2011). Alongside the DCLs and AGOs, RNA-dependent RNA polymerases (RDRs) are also part of the biochemical core of RNA silencing, mediating 
systemic spread of silencing signals through the amplification of primary vsiRNAs (Ding and Voinnet 2007; Himber et al. 2003).

RNA-based antiviral defense involves the activation of specific silencing pathways, such as the posttranscriptional gene-silencing (PTGS) pathway, whose association with the onset of symptom recovery has been well-established (Ghoshal and Sanfaçon 2015; Kørner et al. 2018; Smith et al. 2011).

Recovery reflects the establishment of a virus-tolerant state, in which infected plants exhibit an obvious attenuation, or disappearance, of disease symptoms despite still containing replicating and infective virus particles (Ghoshal and Sanfaçon 2015; Kørner et al. 2018; Križnik et al. 2020).

On the other hand, many, if not all, viruses have evolved various mechanisms to overcome host antiviral defenses, among which the most important is the expression of viral suppressors of RNA silencing (VSRs) (Pumplin and Voinnet 2013; Voinnet 2005). VSRs can suppress antiviral silencing through different strategies, including siRNA sequestration (Ye et al. 2003), inactivation of silencing effector proteins (Chiu et al. 2010; X. Zhang et al. 2012), impairment of siRNA production or disrupting their stability (Cuellar et al. 2009), and hijacking of amplification of the silencing signal (Guo et al. 2013).

As RNA silencing is related to the attenuation of symptoms, the ability of certain viruses to overcome the RNA-based defense has been assumed as the main factor by which symptomatic phenotype may be restored (Senda et al. 2004; Voinnet 2005).

In this work, RNA-mediated antiviral responses were investigated in $N$. benthamiana plants agroinoculated with the pRI::GPGV-vir infectious clone (Tarquini et al. 2019a and b). Genes involved in antiviral defense against GPGV infection were predicted by in silico analyses and their participation was experimentally confirmed via quantitative reverse transcription-PCR (RT-qPCR).

The putative ability of the virus to overcome RNA-mediated antiviral defenses by encoding VSRs was also evaluated using RNA silencing-suppression assays (Voinnet et al. 1999) and with the aid of a newly introduced assay based on stem-loop RT-qPCR (Chen et al. 2005; Cheng et al. 2009; Varkonyi-Gasic et al. 2007) for the quantification of green fluorescent protein (GFP)-derived small interfering RNAs (siRNAs) (Chen et al. 2005; Cheng et al. 2009; Varkonyi-Gasic et al. 2007).

\section{RESULTS}

\section{Prediction of the RNA silencing pathway involved in plant responses to GPGV infection.}

High-throughput sequencing data from 16 small RNA (sRNA) libraries produced by Czotter et al. (2018) were retrieved and were analyzed for the presence of vsRNAs generated from the GPGV viral genome. Of $150,653,830$ sequencing reads, 398,983 $(0.26 \%)$ were mapped to the sequence of fvg-12 isolate (NCBI accession number MH087443 [Tarquini et al. 2019a and b]), which corresponds to the pRI::GPGV-vir clone. The abundant sequencing coverage allowed us to deduce the siRNA processing of the GPGV genome. Indeed, siRNAs were distributed throughout the entire genome sequence, although several hotspots could be detected (Fig. 1A). Hotspots were located both in the replicase gene, at the $5^{\prime}$ end and along the initial $2.1 \mathrm{Kbs}$, and at the $3^{\prime}$ end of the intergenic region between the movement and coat protein coding sequences (Fig. 1A). The analysis of size distribution showed a major accumulation of 21- and 22-nt-long vsRNAs, the former type being more prominent, while the nucleotide composition at their $5^{\prime}$ ends was enriched in uridine and cytosine (Fig. 1B).

\section{Expression analyses of genes involved in the predicted} RNA silencing pathway in GPGV-infected plants.

Before gene expression analyses, $N$. benthamiana wild-type (wt) plants were tested for the presence of the virus, with
RT-qPCR. The upper, noninfiltrated leaves of plants inoculated with the pRI::GPGV-vir were positive for GPGV, showing cycle threshold values lower than 34 (Bianchi et al. 2015) that ranged from 26.25 to 29.37 . Otherwise, both healthy and mock-inoculated plants proved negative to GPGV.

To check whether DCL4, AGO1, AGO5, and RDR6 genes were involved in the antiviral response to GPGV infection, their expression was examined in healthy, GPGV-infected, and mockinoculated $N$. benthamiana wt plants. Gene expression analyses are reported in Figure $2 \mathrm{~A}$ to $\mathrm{D}$, in which the mean normalized expression (MNE) of each gene is plotted as the transcript abundance compared with the $N$. benthamiana protein phosphatase 2A (NbPP2A) expression level (set at 200). In comparison with healthy and mock inoculated plants, those inoculated with the pRI::GPGV-vir clone exhibited a significant upregulation of the NbDCL4, NbAGO5, and NbRDR6 genes (Fig. 2A to C), whereas the expression level of $N b A G O 1$ was inhibited (Fig. 2D). NbAGO5 (Fig. 2B) and NbAGO1 (Fig. 2D) showed the lowest and the highest gene transcription levels, with average MNE values of 4.165 and 51.38, respectively, while the average MNE values of NbDCLA (Fig. 2A) and NbRDR6 (Fig. 2C) were 9.63 and 25.82 , respectively. One-way analysis of variance (ANOVA) and Tukey's honestly significant difference (HSD) post hoc test of the MNE values revealed that the NbDCL4, NbAGO5, and NbRDR6 genes were significantly upregulated in pRI::GPGV-vir-inoculated plants $(P<0.005)$. At the same time, the NbAGO1 gene showed a significant decrease in transcription levels in pRI::GPGV-vir-infected plants $(P<0.005)$. No significant differences were detected among the expression levels of each gene in healthy and mock-inoculated plants (Fig. 2A to D).

\section{Quantification of GFP using fluorescence microscopy.}

The ability of $N$. benthamiana wt plants to spontaneously silence exogenous GFP transgenes (Kalantidis et al. 2006) offers a straightforward method to evaluate the inhibition of RNA silencing in the presence of putative viral suppressors. Thus, the GFP signal was initially evaluated with fluorescence microscopy observations in silenced wt $N$. benthamiana plants and in plants coinoculated with p35S-GFP and either pP19, pGUS, pGPGV REP, $\mathrm{pGPGV}_{\mathrm{MP}}$, or $\mathrm{pGPGV} \mathrm{CP}_{\mathrm{CP}}$. In leaves of $16 \mathrm{c}$ plants coinoculated with $\mathrm{p} 35 \mathrm{~S}-\mathrm{GFP}$ and either $\mathrm{pGPGV} \mathrm{REP}_{\mathrm{RE}}$ or $\mathrm{pGPGV}_{\mathrm{MP}}$, no fluorescent signals were detected (Fig. $3 \mathrm{~A}$ and $\mathrm{B}$ ). On the other hand, leaves coinoculated with p35S-GFP and either $\mathrm{pGPGV}_{\mathrm{CP}}$ (Fig. 3C) or p19 (Fig. 3F) showed a GFP signal all over the leaf surface. Leaves of silenced $16 \mathrm{c}$ plants and those coinoculated with $\mathrm{p} 35 \mathrm{~S}-\mathrm{GFP}$ and $\mathrm{pGUS}$ were observed with the same excitation wavelength used in the other experimental conditions, and no fluorescent signals were detected (Fig. 3D). The interpretation of the observations was corroborated with fluorescence quantification analysis that revealed strong fluorescence in leaves coinoculated with p35S-GFP and $\mathrm{pGPGV}_{\mathrm{CP}}$, similar to those coinoculated with pP19 (Fig. 3C to F). Fluorescent microscopy observations (Fig. 3) suggested that GPGV coat protein (CP) is a suppressor of RNA silencing, exhibiting VSR activity similarly to the known p19 suppressor tested in this study.

\section{Quantification of GFP messenger RNA (mRNA) by real-time PCR.}

To obtain further quantitative data on the ability of one or more GPGV proteins to overcome the plant antiviral response through suppression of antiviral RNA silencing, the expression level of GFP mRNA was evaluated in noninoculated and silenced $16 \mathrm{c}$ $N$. benthamiana plants and in plants coinoculated with p35SGFP and either pP19, pGUS, pGPGV $\mathrm{REP}_{\mathrm{R}}, \mathrm{pGPGV}_{\mathrm{MP}}$, or $\mathrm{pGPGV}_{\mathrm{CP}}$. The analysis of GFP mRNA expression is presented in Figure 4, in which the MNE of GFP mRNA is plotted as the transcript abundance relative to the $N b F$-box expression level 
(set at 200). The highest and lowest GFP transcription levels were observed in noninoculated (MNE value of $10.75 \times 10^{4}$ ) and silenced (MNE value of $3.13 \times 10^{4}$ ) $16 \mathrm{c}$ plants, respectively. The 16c plants coinoculated with p35S-GFP and either pGPGV $\mathrm{REP}_{\mathrm{RE}}$ or $\mathrm{pGPGV} \mathrm{V}_{\mathrm{MP}}$ revealed similar expression levels of GFP mRNA, having MNE values of $2.23 \times 10^{4}$ and $3.56 \times 10^{4}$, respectively.

On the other hand, high levels of GFP expression were detected in $16 \mathrm{c}$ plants coinoculated with $\mathrm{p} 35 \mathrm{~S}-\mathrm{GFP}$ and $\mathrm{pGPGV} \mathrm{CP}_{\mathrm{CP}}(\mathrm{MNE}$ value of $6.68 \times 10^{4}$ ) and in plants coinoculated with p35S-GFP and the pP19 viral suppressor (MNE values of $7.12 \times 10^{4}$ ). According to one-way ANOVA and Tukey's HSD post hoc test of the MNE, the GFP expression level in 16c plants coinoculated with p35S-GFP and pGPGV $_{\mathrm{CP}}$ as well as the levels detected in plants coinoculated with p35S-GFP and pP19, were significantly higher than the GFP levels reported in 16c plants inoculated with p35S-GFP alone (silenced plants, $P<0.05$ ). In contrast, the GFP transcription levels in $16 \mathrm{c}$ plants coinoculated with p35S-GFP and either GPGV $_{\text {REP }}$ or pGPGV $_{\text {MP }}$ were comparable to those detected in silenced $16 \mathrm{c}$ plants $(P>0.05)$. The qPCR
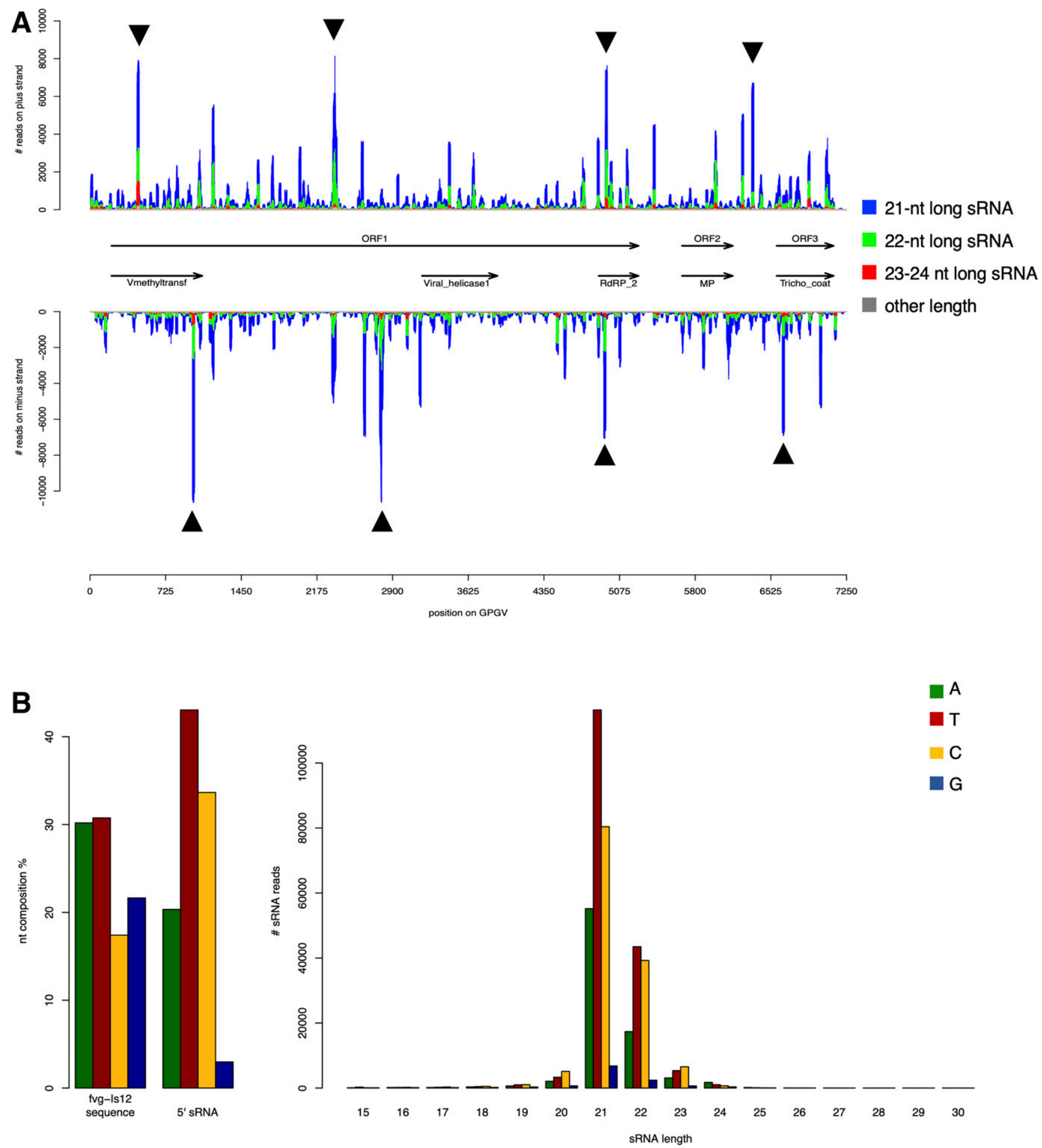

Fig. 1. In silico prediction of the genome distribution and profile of grapevine Pinot gris virus (GPGV)-derived small interfering RNAs (siRNAs). A, GPGVderived siRNAs are distributed along the entire viral genome. Several hotspots indicating abundant siRNA biogenesis were also detected (arrowheads). B, Analysis of size and $5^{\prime}$-terminal nucleotide composition revealed that GPGV-derived siRNAs are $21 \mathrm{nt}$ long and are enriched in $5^{\prime}$ cytosine and $5^{\prime}$ uridine. 
experiments were in agreement with the results obtained with fluorescent microscopy observations, demonstrating that plants coinoculated with $\mathrm{p} 35 \mathrm{~S}-\mathrm{GFP}$ and $\mathrm{pGPGV}_{\mathrm{CP}}$ showed a significant increase in GFP transcripts, similar to those detected in plants coinoculated with p35S-GFP and p19 (Fig. 4).

\section{Quantification of GFP-derived siRNA by real-time looped RT-PCR.}

The level of GFP-derived siRNAs was assessed at the locus corresponding to the $\mathrm{P} 2$ probe (P2-derived GFP siRNA), which has been previously reported as a representative hotspot for the GFP-derived siRNA population (Christie et al. 2011). Accumulation of P2-derived GFP siRNAs was determined in silenced 16c $N$. benthamiana plants and in plants coinoculated with p35SGFP and either pP19, pGUS, or pGPGV $\mathrm{CP}_{\mathrm{CP}}$. Analysis of siRNA quantification is reported in Figure 5. The MNE of P2-derived GFP siRNAs is plotted as the siRNA abundance relative to the U6 small nuclear RNA (snRNA) expression level (set at 200). The lowest MNE value (0.032), corresponding to the lowest level of P2-derived GFP siRNAs, was detected in 16c plants inoculated
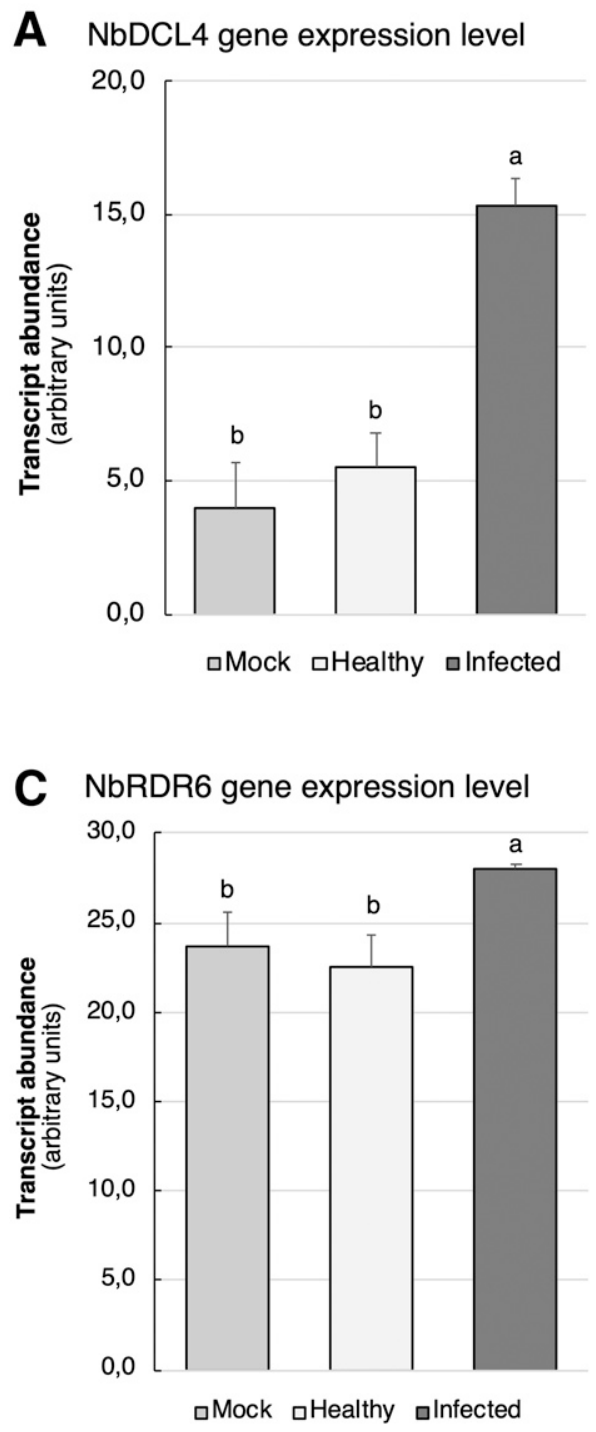

with only pGUS. Otherwise, the highest level of P2-derived GFP siRNA (MNE value of 0.11 ) was measured in silenced $16 \mathrm{c}$ plants. Plants coinoculated with p35S-GFP and the p19 viral suppressor exhibited a threefold reduced level of P2-derived GFP siRNA in comparison with silenced plants and had MNE values of 0.04 . Similarly, the levels of P2-derived GFP siRNAs in 16c plants coinoculated with $\mathrm{p} 35 \mathrm{~S}-\mathrm{GFP}$ and $\mathrm{pGPGV} \mathrm{CP}_{\mathrm{CP}}$ were reduced by a factor of 2 relative to silenced plants (MNE value of 0.06). Oneway ANOVA and Tukey's HSD test demonstrated that the level of P2-derived GFP siRNAs in 16c plants coinoculated with $\mathrm{p} 35 \mathrm{~S}-\mathrm{GFP}$ and either $\mathrm{pGPGV}_{\mathrm{CP}}$ or the $\mathrm{p} 19$ viral suppressor was significantly decreased in comparison with the siRNA levels detected in silenced $16 \mathrm{c}$ plants $(P<0.05)$. The $16 \mathrm{c}$ plants coinoculated with $\mathrm{p} 35 \mathrm{~S}-\mathrm{GFP}$ and $\mathrm{pGPGV}_{\mathrm{CP}}$ showed a decline in P2-derived GFP siRNAs that did not differ significantly from the levels observed in 16c plants coinoculated with p35S-GFP and p19 viral suppressor $(P>0.05)$. The accumulation of P2-derived GFP siRNAs in silenced 16c plants was comparable to observations in mock coinfiltrated $16 \mathrm{c}$ plants, showing no statistically significant differences $(P>0.05)$. The quantitative analysis
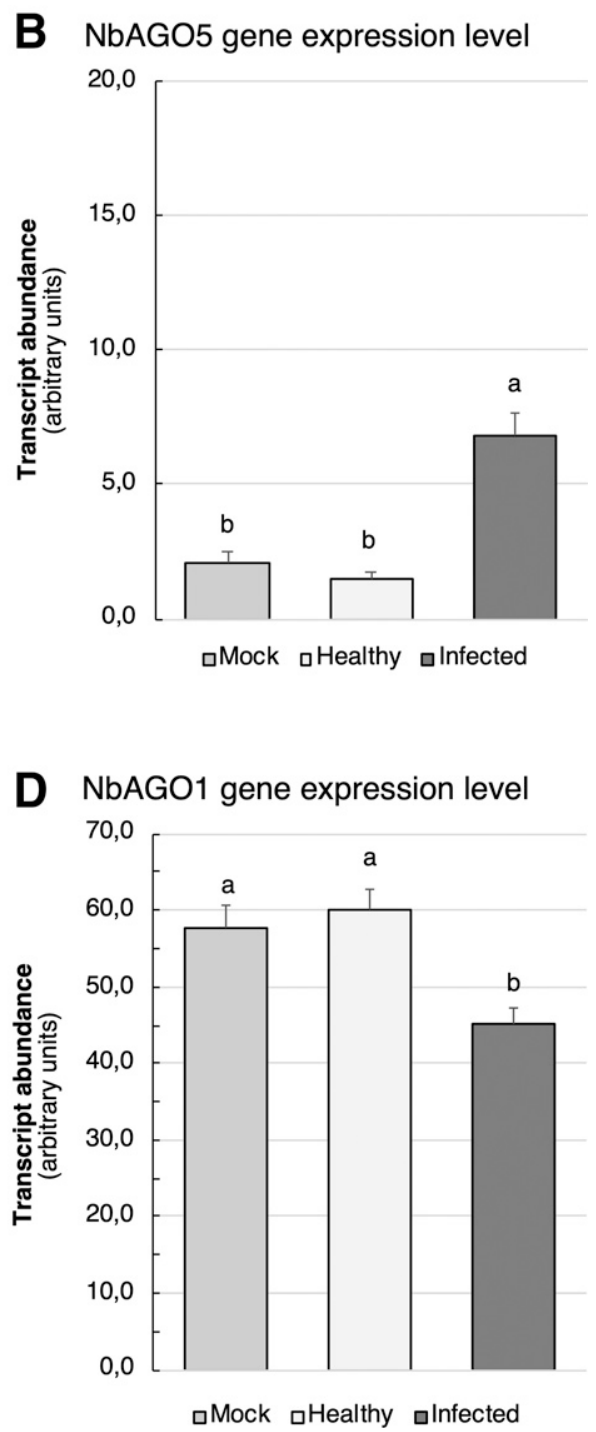

Fig. 2. Gene expression levels of healthy, grapevine Pinot gris virus (GPGV)-infected, and mock-inoculated wild-type Nicotiana benthamiana plants. A, The gene expression levels of NbDCL4, B, NbAGO5, C, NbRDR6, and D, NbAGO1 were analyzed in healthy, GPGV-infected, and mock-inoculated plants of $N$. benthamiana wild-type plants, using quantitative quantitative reverse transcription-PCR. Expression values were normalized to the PP2A transcript level, arbitrarily fixed at 200, and were then expressed as mean normalized expression \pm standard deviation (transcript abundance). NbDCL4, NbAGO, and NbRDR6 were significantly upregulated in infected plants compared with healthy plants, while NbAGO1 was significantly downregulated. No significant differences in gene expression levels were detected in healthy and mock-inoculated plants. 
of P2-derived GFP siRNAs accumulation were fully consistent with results obtained by fluorescent microscopy observations and qPCR experiments, further demonstrating the ability of GPGV-CP to overcome plant defense response by suppressing antiviral RNA silencing.

\section{DISCUSSION}

In the last decade, an emerging trichovirus known as GPGV was suggested as the aetiological agent of the novel grapevine disease known as GLMD. The ambiguous symptom expression in GPGV-infected grapevines raised many doubts about the role if the virus in GLMD disease (Bertazzon et al. 2017; Bianchi et al. 2015; Saldarelli et al. 2015; Tarquini et al. 2018; 2019a and b). Different aspects have been investigated as putative "interfering factors" in the display of GLMD symptoms (Buoso et al. 2020; Tarquini et al. 2018; 2019a and b), but an exhaustive explanation of the phenomenon at the molecu; lar level is missing.

Since virus-mediated RNA silencing may play a role in this context, the main purpose of this work was to investigate the
RNA-silencing pathway that mediates the plant response to GPGV infection. Moreover, the putative ability of the virus to overcome antiviral defenses by suppressing the RNA silencing mechanism was also evaluated.

Plants possess a large variety of RNA silencing pathways mediated by diverse DCL and AGO enzymes, which underpins the production of specific siRNAs involved in distinct biological processes (Bologna and Voinnet 2014; Brodersen and Voinnet 2006; Voinnet 2009). The dominant action of certain Dicer enzymes underlies both the size and the $5^{\prime}$-nucleotide identity of siRNAs, strongly influencing their partitioning into a specific AGO protein and, ultimately, their biological function (Bologna and Voinnet 2014; Mi et al. 2008).

In silico investigations of siRNA libraries of $V$. vinifera (Czotter et al. 2018) have revealed the abundance of 21-nt-long, $5^{\prime}$ terminal cytosine- and uridine-enriched GPGV-derived siRNAs, which suggests the participation of DCL4 and AGO1/AGO5 in RNAbased antiviral defense (Bologna and Voinnet 2014; Dunoyer et al. 2005; Henderson et al. 2006; Mi et al. 2008). The predicted
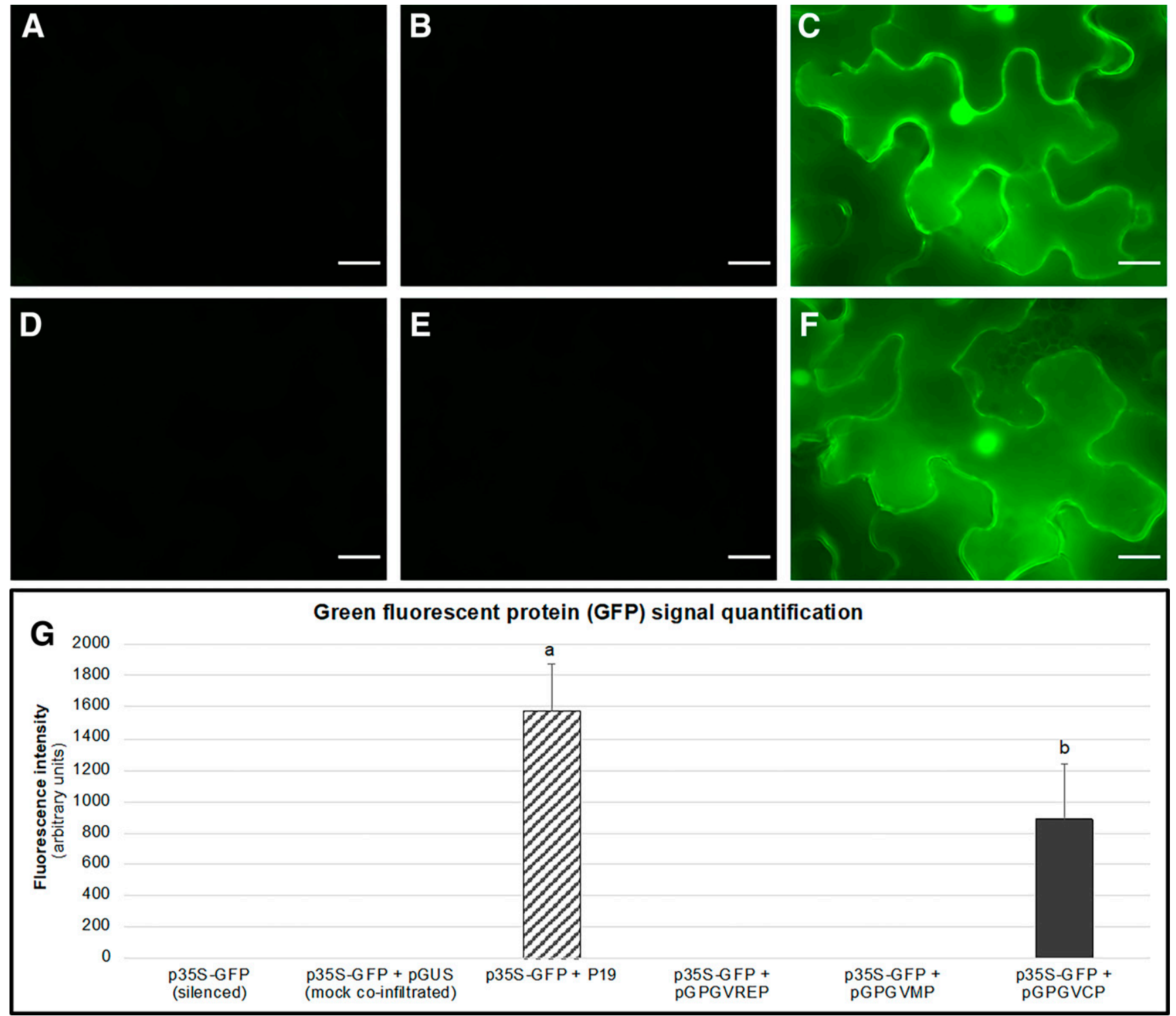

Fig. 3. Green fluorescent protein (GFP) signal in sections of fresh tissue from Nicotiana benthamiana wild-type plants. No GFP fluorescence was detected in either A, silenced plants or $\mathbf{B}$, in mock coinfiltrated plants. C, In plants coinoculated with p35S-GFP and the pP19 viral suppressor, GFP signal was significantly detected. D, Leaves coinoculated with p35S-GFP and either pGPGV REP $_{\text {or }} \mathbf{E}$, pGPGV $\mathrm{MP}_{\mathrm{MP}}$ ho fluorescence signals. F, Plants coinoculated with p35S-GFP and $\mathrm{pGPGV}_{\mathrm{CP}}$ appeared to emit a strong signal, comparable to those in C. G, Fluorescence quantification analysis revealed a strong signal in

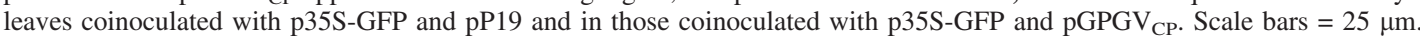


enzymes, together with RDR6, represent the biochemical core of the PTGS mechanism, which was assumed to be a silencing pathway that mediates plant responses to GPGV infection (Kørner et al. 2018; Voinnet 2008).

To provide experimental validation about the involvement of the plant enzymes in GLMD disease, the expression level of DCL4, AGO1, AGO5 and RDR6 genes was assessed in distal leaves of $N$. benthamiana wt plants inoculated with either the infectious clones of the virus (pRI::GPGV-vir) (Tarquini et al. 2019a and b) or the pRI empty-vector (mock inoculated) and in noninoculated (healthy) plants. Gene expression assays confirmed in silico analyses, demonstrating that the DCL4, AGO5 and RDR6 genes were significantly up-regulated in GPGV-infected plants compared with healthy plants.

The contribution of DCL4 in RNA silencing-mediated antiviral immunity is well-documented (Bologna and Voinnet 2014; Parent et al. 2015; Pumplin and Voinnet 2013; Qin et al. 2017; Yang and Li 2018). DCL4-dependent 21-nt vsiRNAs were found to be required for cell-to-cell signaling (Dunoyer et al. 2005), limiting virus spread within vascular tissues, and inhibiting the onset of systemic infection (Deleris et al. 2006; Dunoyer et al. 2005; Parent et al. 2015; Qin et al. 2017). Biogenesis of vsiRNAs requires the coordinated and hierarchical action of DCL enzymes, particularly DCL4 and, to a lesser extent, DCL2 (Szittya and Burgyán 2013). The latter plays a surrogate antiviral role and operates exclusively when DCL4 is suppressed or inactivated, rescuing antiviral defense (Deleris et al. 2006). In our study, the involvement of DCL2 in the antiviral RNA silencing mediating plant response to GPGV infection was not investigated. The significant upregulation of DCL4 observed in GPGV-infected $N$. benthamiana wt plants suggested the proper antiviral activity of the enzyme, discarding the possibility of eventual impairment that may have suggested the hierarchical activation of DCL2 (Deleris et al. 2006; Parent et al. 2015; Qin et al. 2017).

The upregulation of RDR6 in N. benthamiana wt plants inoculated with the infectious clone of the virus, which suggests an increased activity of the enzyme, can be related by the production of 21-nt secondary siRNAs, which contribute to the systemic spread of the RNA silencing signal. The hypothesis that RDR6 is involved in the spread of antiviral silencing was further supported by the significant reduction in virus titer reported at later stages of infection, both in GPGV-infected grapevines grown in the field (Bertazzon et al. 2017; Bianchi et al. 2015) and from 4 to 5 months post inoculum in agrodrenched plants (Tarquini et al.

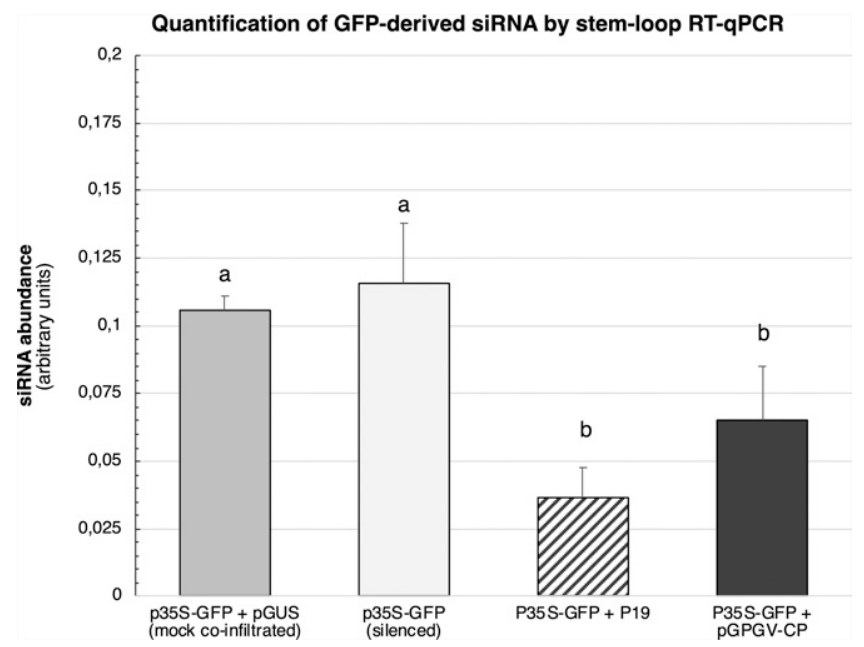

Fig. 5. Quantification of P2-derived green fluorescent protein (GFP) small interfering RNAs (siRNAs) in GFP-transgenic Nicotiana benthamiana $16 \mathrm{c}$ plants. The accumulation of GFP-derived siRNAs was evaluated in silenced and mock coinfiltrated $16 \mathrm{c}$ plants and in plants coinoculated with $\mathrm{p} 35 \mathrm{~S}-\mathrm{GFP}$ and either $\mathrm{pGPGV}_{\mathrm{CP}}$ or P19, using stem-loop quantitative reverse transcription-PCR assays. The highest level of P2-derived GFP siRNAs were detected in silenced and mock coinfiltrated plants, whereas lower levels of P2-derived GFP siRNAs were observed in 16c plants coinoculated with p35S-GFP and either $\mathrm{pGPGV}_{\mathrm{CP}}$ or P19.

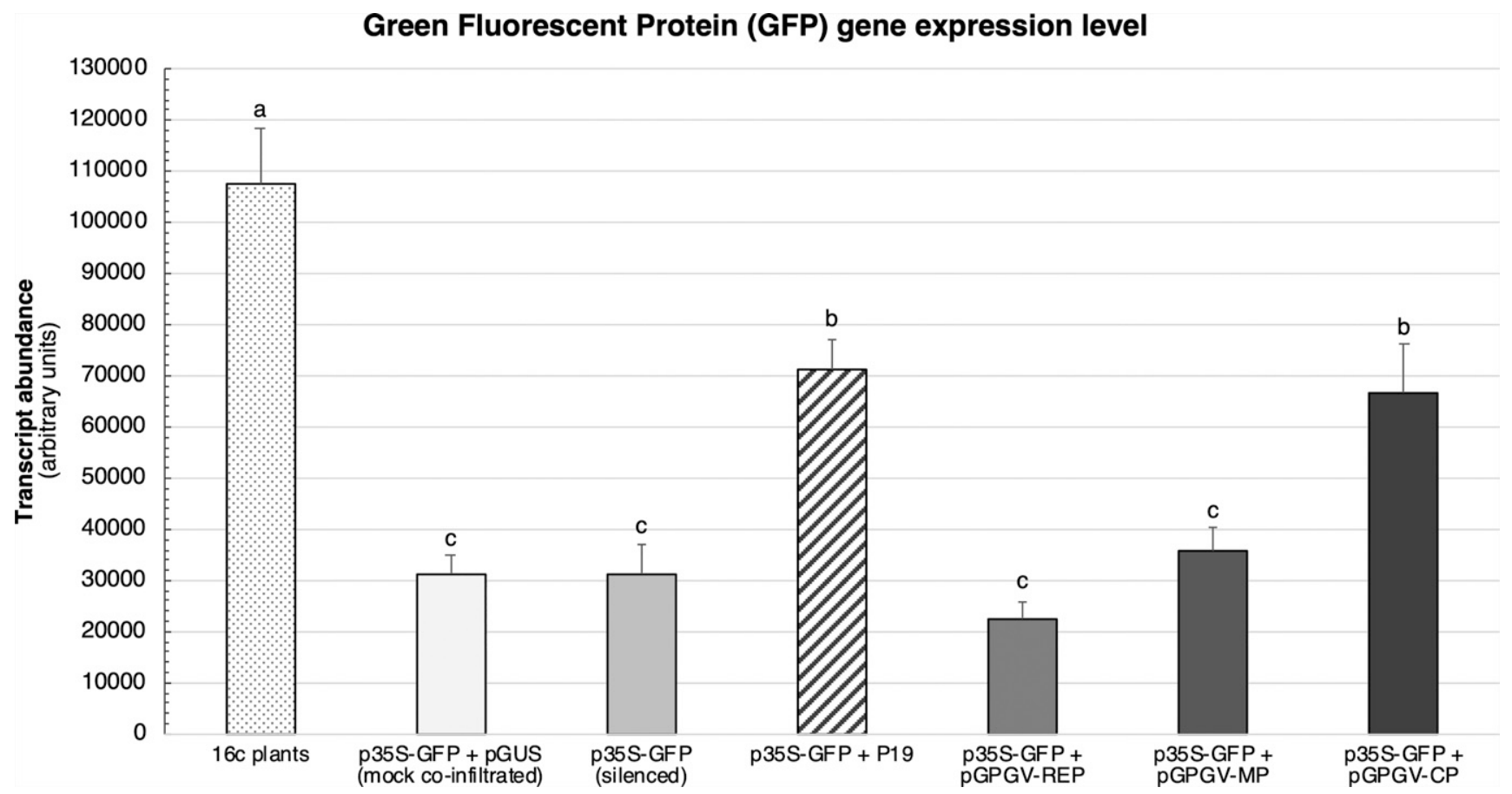

Fig. 4. Expression level of green fluorescent protein (GFP) messenger RNA (mRNA) in GFP-transgenic Nicotiana benthamiana 16c plants as a result of quantitative reverse transcription-PCR. Noninoculated 16c plants showed the highest level of GFP expression. Expression levels of GFP in silenced and mock coinfiltrated plants were significantly downregulated in comparison with noninoculated plants. Plants coinoculated with p35S-GFP and either $\mathrm{pGPGV}_{\mathrm{REP}}$ or $\mathrm{pGPGV}_{\mathrm{MP}}$ exhibited a decrease in GFP expression levels that was comparable to silenced plants. Plants coinoculated with p35S-GFP and pP19 revealed a restoration of GFP expression levels that was comparable to plants coinoculated with p35S-GFP and pGPGV $\mathrm{CP}_{\mathrm{C}}$. 
2019a and b). A causal relationship between high levels of viral RNAs and a low level of RDR6-dependent vsRNAs was reported in rdr6-deficient Arabidopsis thaliana and compellingly implicated RDR6 in antiviral defense (Andika et al. 2013; Qu 2010; Wang et al. 2010).

The activity of RDR6, which should contribute to the spread of antiviral defense in GLMD disease through amplification of GPGV-derived siRNAs, provides a reasonable explanation about the decrease in the viral titer at later stages of infection.

Although in silico prediction suggested a possible role of both AGO1 and AGO5 in GLMD disease, the exclusive involvement of AGO1 was erroneously hypothesized, which was mainly due to its better-characterized antiviral function (Carbonell and Carrington 2015; Garcia-Ruiz et al. 2015; Zhang et al. 2006). Interestingly, AGO1 was inhibited in GPGV agroinoculated plants, while AGO5 was strongly upregulated. The antiviral role of AGO5 has been reported for several plant viruses (Brosseau and Moffett 2015; Carbonell and Carrington 2015; Garcia-Ruiz et al. 2015; Takeda et al. 2008). The enzyme binds preferentially to 21-nt siRNAs with a $5^{\prime}$ cytosine (Schuck et al. 2013), such as those predicted to be involved in GPGV-host interaction.

Consistent with observations in GPGV-infected plants, a significant upregulation of AGO5 was reported exclusively in phloem tissues of plants infected with plum pox virus (Collum et al. 2020). Unlike the near-ubiquitously expressed AGO1 (Marchais et al. 2019), the upregulation of AGO5 in phloem tissues reflects the cell-specific activity of the enzyme, which mainly functions in the phloem (Collum et al. 2020) and reproductive tissues (Roussin-Léveillée et al. 2019; Van Ex et al. 2011).

The phloematic activity of AGO5 is consistent with the subcellular localization of GPGV particles, which were exclusively detected in the bundle sheath cells in proximity to the phloem tissue (Tarquini et al. 2018), further supporting the participation of the enzyme in antiviral defense.

As is now well-established for AGO1 (Axtell 2017; Brodersen et al. 2012; Lanet et al. 2009; Li et al. 2013; Michaeli et al. 2019; Reynoso et al. 2013), AGO5 was also found to recruit siRNAs associated with endoplasmic reticulum (ER)-bound polysomes (Marchais et al. 2019).

The involvement of ER in GLMD disease was previously hypothesized (Tarquini et al. 2018, 2019a and b), and it has been currently validated by ultrastructural and functional studies (G. Tarquini unpublished results). The deformed membranebound organelles observed in grapevines that are naturallyinfected by GPGV (Tarquini et al. 2018) and those agrodrenched with the infectious clones of the virus (pRI::GPGV-vir and pRI::GPGV-lat) (Tarquini et al. 2019a and b), were found to derive from altered ER, which served as the viral replication complex (Romero-Brey and Bartenschlager 2016; Schaad et al. 1997).

In addition to providing a protected environment for viral replication, the rough ER (rER) is the site where siRNA-mediated silencing and microRNA (miRNA)-mediated translational repression occur (Kim et al. 2014). One scenario supported by current evidence for the progression of molecular events mediating GPGV-host interaction includes the production of GPGVderived siRNAs directly within the lumen of the altered ER. Here, dsRNA precursors would be produced during virus replication, with subsequent prompt recruitment by AGO5 in the same location.

A similar mechanism was described for RNA interference in mammalian cells, in which the outer rER membranes provide a scaffold for the anchoring of AGO2-dependent siRNA (Stalder et al. 2013).

The simultaneous upregulation of AGO5 and inhibition of AGO1 in GPGV-infected plants has been described previously in Arabidopsis thaliana plants infected with potato virus $\mathrm{X}$ (PVX) (Brosseau and Moffett 2015; Chiu et al. 2010). In this system, the antiviral function of AGO1 was strongly suppressed by the PVX-encoded P25 viral suppressor, which did not seem to affect AGO5 (Brosseau and Moffett 2015). This aspect is highly relevant for the characterization of GPGV-host interaction, considering that, in the current work, the CP encoded by GPGV was found to suppress RNA silencing.

We evaluated the putative ability to suppress the RNA silencing mechanism by comparing GFP signals, both by fluorescence microscopy (Chiera et al. 2008) and RT-qPCR assays (Amin et al. 2011) in silenced plants and in plants coinoculated with p35S-GFP and either $\mathrm{pGPGV}_{\mathrm{CP}}$ or $\mathrm{pP} 19$. Moreover, as an indirect means to evaluate the increase or decrease in the levels of siRNAs, the amount of siRNA generated that corresponded to a specific hotspot in the GFP sequence (P2-derived GFP siRNA) was also assessed by using a stem-loop RT-qPCR approach.

The standard procedure for the quantification of sRNA molecules is based on Northern blot hybridization, which is timeconsuming, requires large amounts of RNA, employs radioactively labeled probes, and often fails to identify sRNAs expressed at low levels (Smoczynska et al. 2019). Since 2004, several PCRbased methods have been developed for the analysis of the expression levels of sRNA molecules, such as miRNAs (Chen et al. 2005; Kramer 2011; Raymond et al. 2005; Sharbati-Tehrani et al. 2008; Shi and Chiang 2005; Turner et al. 2013; Varkonyi-Gasic et al. 2007; Yang et al. 2014) and artificial siRNAs (Cheng et al. 2009; Czimmerer et al. 2013; Marcial-Quino et al. 2016; Raymond et al. 2005). Among these, a widely used method is the stem-loop RT-qPCR assay, which relies on pulsed RT in the presence of an siRNA-specific stem-loop primer (Chen et al. 2005, 2011; Turner et al. 2013; Varkonyi-Gasic et al. 2007; Yang et al. 2014).

A 21-nt GFP probe (named P2) employed in a previous study was assumed as a representative target for the construction of the $3^{\prime}$-end extension of the GFP stem-loop primer due to the reported accuracy and reliability in detecting differences in GFP-derived siRNAs between exons from intronless versus intron-containing GFP transgenes, resulting in a significant hotspot for siRNA biogenesis (Christie et al. 2011).

In comparison with silenced plants, the stronger GFP fluorescence signal and the higher GFP-mRNA transcription level (consistent with the lower siRNA amounts estimated by P2-derived GFP siRNA stem-loop RT-qPCR) that was observed in plants coinoculated with $\mathrm{p} 35 \mathrm{~S}-\mathrm{GFP}$ and either $\mathrm{pGPGV}_{\mathrm{CP}}$ or pP19, demonstrated unequivocally the ability of GPGV CP to suppress plant RNA silencing in a similar way to the well-known p19 viral suppressor.

VSR is a general strategy used by many, if not all, viruses to overcome plant antiviral defenses (Moissiard and Voinnet 2004; Voinnet 2005; Voinnet et al. 1999). It relies on the ability of certain viral proteins to interfere at diverse levels of the antiviral silencing cascade and through different modes of action (Pumplin and Voinnet 2013). Some VSRs, such as the turnip crinkle virus-encoded P38 protein (Azevedo et al. 2010; Zhang et al. 2012 ), the $2 \mathrm{~b}$ protein of cucumber mosaic virus (Duan et al. 2012), and the P25 protein of PVX (Chiu et al. 2010), inactivate or compromise the functioning of silencing effector proteins. Otherwise, VSRs can impair the production of vsiRNAs, interfering with their stability (Cuellar et al. 2009) or directly interacting with the DCL4 enzyme (Laird et al. 2013). Finally, some VSRs can also act at the level of silencing amplification to prevent the systemic spread of the silencing response, altering the functioning of RDR6 and blocking the synthesis of secondary siRNAs (Guo and Ding 2002; Guo et al. 2013).

The mechanism by which GPGV CP suppresses the antiviral silencing has not yet been defined, although the strong inhibition of AGO1, previously reported by Chiu et al. (2010) and Brosseau and Moffett (2015) as a target of the P25 suppressor, may suggest its role as putative target of GPGV CP. 
Overall, this investigation initiates the study of GPGV-host interaction, revealing the ability of the virus to both trigger and suppress the plant antiviral response. Considering the significant contribution of the PTGS pathway in symptom recovery (Ghoshal and Sanfaçon 2015) as well as the crucial role of VSR in restoration of symptomatic phenotype (Kørner et al. 2018; Moissiard and Voinnet 2004; Senda et al. 2004; Zhang et al. 2020), the intriguing GPGV-plant interaction should provide the initial clues for a molecular interpretation of the puzzling field observations on disease symptomatology.

\section{MATERIALS AND METHODS}

Plant material.

$N$. benthamiana wt and GFP-transgenic (16c line) (Ruiz et al.1998) plants were grown from seed in a growth chamber at $25^{\circ} \mathrm{C}$ and with a16-h-light and 8-h-dark cycle. After inoculation, plants were kept in the same conditions.

\section{Plasmid construction.}

An infectious clone of GPGV (pRI::GPGV-vir), obtained as previously described by Tarquini et al. (2019a and b), was used to trigger antiviral RNA silencing responses in wt $N$. benthamiana plants.

The putative ability of GPGV to overcome plant antiviral defense by suppression of RNA silencing was also investigated. Cloning of FHA ( $2 \times$ FLAG and $2 \times$ hemagglutinin)-tagged viral proteins was performed using multisite Gateway technology (Invitrogen). The entire coding sequence of the replicase (REP), movement protein (MP), and CP was PCR-amplified from pRI::GPGV-vir (accession number MH087443 [Tarquini et al. 2019a and b]) using Phusion High-Fidelity DNA polymerase (Thermo Scientific). Primer sequences are listed in Table 1. The complementary DNAs (cDNAs) were singularly recombined into the pDONR P2R-P3 plasmid, using BP clonase II (Invitrogen), and the resulting clones were sequenced for authenticity. A constitutive promoter clone $\mathrm{pUB}_{10}$ (Arabidopsis Ubiquitin-10) and a plasmid containing FHA-tag (pFHA) were obtained as described by Devers et al. (2020).

The final vectors were created by recombining individual GPGV proteins with the constitutive promoter $\left(\mathrm{pUB}_{10}\right)$ and the FLAG epitope (pFHA) into the destination vector $\mathrm{pK} 7 \mathrm{~m} 34 \mathrm{GW}$ (Karimi et al. 2005) using LR clonase II (Invitrogen). The resulting expression cassettes, $\mathrm{pUBI}_{10}$-FHA-REP (pGPGV $\left.\mathrm{REP}_{\mathrm{REP}}\right), \quad \mathrm{pUBI}_{10}$-FHA-MP $\left(\mathrm{pGPGV}_{\mathrm{MP}}\right)$, and $\mathrm{pUBI}_{10}-\mathrm{FHA}-\mathrm{CP}\left(\mathrm{pGPGV}_{\mathrm{CP}}\right)$ (Fig. 6) were transformed into Agrobacterium tumefaciens GV3101 chemically competent cells.

\section{Agroinoculation of pRI::GPGV-vir into $N$. benthamiana wt plants.}

Three-week-old $N$. benthamiana wt plants were inoculated with the pRI::GPGV-vir clone and were assumed as infected. Noninoculated plants were assumed as control (healthy), while plants inoculated with the empty vector (pRI101AN-DNA; Clontech Laboratories-Takara Bio USA, Inc.) were regarded as mockinoculated (mock). For the inoculation, three leaves of approximately equal size on a single plant were infiltrated as described by Tarquini and coauthors (2019a and b). A total of nine plants, three per experimental condition, were used. Three upper, noninfiltrated leaves per plant were harvested 1 week post inoculum, were pooled, and were immediately frozen and stored at $-80^{\circ} \mathrm{C}$ for RNA isolation. The inoculation was repeated three times in independent experiments.

\section{Agrobacterium coinfiltration assay \\ in $N$. benthamiana $16 \mathrm{c}$ plants. \\ A single colony of A. tumefaciens GV3101 harboring pGPGV $\mathrm{REP}_{\text {, }}$ $\mathrm{pGPGV}_{\mathrm{MP}}$, or $\mathrm{pGPGV}_{\mathrm{CP}}$ was inoculated into $10 \mathrm{ml}$ of Luria}

Bertani medium supplemented with rifampicin $(50 \mu \mathrm{g} / \mathrm{ml})$, gentamicin $(100 \mu \mathrm{g} / \mathrm{ml})$, and spectinomycin $(100 \mu \mathrm{g} / \mathrm{ml})$. Cultures were incubated overnight at $28^{\circ} \mathrm{C}$ with constant shaking $(220 \mathrm{rpm})$ and cells were harvested by centrifugation at $3,000 \times g$ for $10 \mathrm{~min}$ at $4^{\circ} \mathrm{C}$. Pellets were resuspended in infiltration medium $(10 \mathrm{mM}$ morpholine ethanesulfonic acid, $\mathrm{pH} 5.8,10 \mathrm{mM} \mathrm{MgCl}_{2}$, and $200 \mu \mathrm{M}$ acetosyringone) and were incubated at room temperature with constant shaking $(220 \mathrm{rpm})$ for $3 \mathrm{~h}$. The p35S-GFP construct (Haseloff et al. 1997) was used as the PTGS inducer (Iki et al. 2017; Ye et al. 2009), while the pP19 plasmid containing the P19 viral suppressor of tomato bushy stunt virus (Baulcombe and Molnár 2004) was assumed as a positive control of antiviral silencing suppression. Before coinfiltration, the optical density at $600 \mathrm{~nm}$ of the A. tumefaciens cultures was adjusted to 1.0. Three leaves of approximately equal size per plant were fully infiltrated with $\mathrm{p} 35 \mathrm{~S}$ GFP, either alone (hereafter indicated as silenced plants) with pP19 or with one of the FHA-tagged GPGV proteins $\left(\mathrm{pGPGV}_{\mathrm{REP}}\right.$, $\mathrm{pGPGV}_{\mathrm{MP}}$, or $\mathrm{pGPGV} \mathrm{CP}_{\mathrm{CP}}$ ). Plants coinoculated with $\mathrm{p} 35 \mathrm{~S}-\mathrm{GFP}$ and the plasmid containing the FHA-tagged $\beta$-glucuronidase protein (pGUS) were assumed as internal controls of the experiment (hereafter indicated as mock coinfiltrated plants). Four plants per each experimental condition were used. Two of three infiltrated leaves per plant were harvested 3 days post inoculum, were pooled, and were immediately frozen and stored at $-80^{\circ} \mathrm{C}$ for RNA extraction, while the remaining leaf was used for fluorescent microscopy observations. All inoculations were repeated three times in independent experiments.

\section{RNA extraction and RT.}

RNA was extracted from wt and 16c $N$. benthamiana plants, using a Spectrum total RNA extraction kit (Sigma Aldrich), according to the procedure described in "Protocol A," which allows the recovery of sRNA molecules. For gene expression assays, $1 \mu \mathrm{g}$ of total RNA was reverse transcribed into cDNA with the recombinant Moloney murine leukemia virus RT (MMLV-RT; Promega), according to the protocol described by Tarquini et al. (2018).

\section{In silico prediction of vsiRNAs involved}

in the antiviral response to GPGV infection.

In silico analyses were carried out to predict the class of vsiRNA produced by the plant in response to GPGV infection. To this end, the 18 siRNA libraries produced by (Czotter et al. 2018) were retrieved from the Short Read Archive (accession number SRP121703). The 1_TK and 11_SZHU libraries were discarded due to the low GPGV coverage (19.74 and $18.19 \%$, respectively) (Czotter et al. 2018). The remaining 16 libraries were pooled and adapter sequences were removed, using the fastx clipper from the FASTX toolkit. After trimming, reads were aligned to the wholegenome sequence of the fvg-12 isolates (GenBank accession number MH087443 [Tarquini et al. 2019a and b]), which corresponds to the pRI::GPGV-vir clone, using Bowtie2 v2.2.1 (Langmead and Salzberg 2012) with default parameters, but using -k 10. Mapped data were then processed using Python and $\mathrm{R}$ scripts to produce a single nucleotide-resolution siRNA profile over the full sequence from the pRI::GPGV-vir.

\section{Expression analyses of genes involved in the predicted RNA silencing pathway.}

Before gene expression analyses, wt $N$. benthamiana plants that were not inoculated (healthy), or were inoculated with either the pRI::GPGV-vir clone, or with pRI empty vector (mock-inoculated) were tested for the presence of the virus via qPCR, as reported by Tarquini et al. (2019a and b).

The expression of genes putatively involved in the predicted RNA silencing pathway, NbDCLA, NbAGO1, NbAGO5, and $N b R D R 6$, was analyzed. The reference gene was individuated by 
comparing NbGAPDH (glyceraldehyde-3-phosphate dehydrogenase), NbF-box, and NbEF- $\alpha$ (alpha elongation factor) gene expression (Liu et al. 2012). The gene stability measures (M values) were calculated according to the geNorm program (Vandesompele et al. 2002) (Table 2). PP2A was found to be one of the most stably expressed genes in $N$. benthamania wt and, hence, the most suitable for use as a reference gene. Real-time PCR experiments were performed on a CFX96 instrument (Bio-Rad
Laboratories). SsoFast EvaGreen Supermix (Bio-Rad Laboratories Inc.), $5 \mathrm{ng}$ of cDNA, and specific primers were used in a total volume of $15 \mu \mathrm{l}$. Every reaction was performed at $95^{\circ} \mathrm{C}$ for $3 \mathrm{~min}, 40$ cycles of $95^{\circ} \mathrm{C}$ for $5 \mathrm{~s}$ and $60^{\circ} \mathrm{C}$ for $5 \mathrm{~s}$, followed by a melting curve analysis from 65 to $95^{\circ} \mathrm{C}$ to check primer specificity. $\mathrm{NbDCLA}$ and $\mathrm{NbAGO1}$ primers were designed on the reference sequences NC_031999.1 and NM_001325505.1, respectively, using Geneious 10.2.6 (Biomatters Ltd.), and their specificity

Table 1. Primers used in this study

\begin{tabular}{|c|c|c|}
\hline Application, primer name ${ }^{a}$ & Primer sequence $\left(5^{\prime} \rightarrow 3^{\prime}\right)^{b}$ & Reference \\
\hline \multicolumn{3}{|l|}{ Gateway cloning } \\
\hline \multirow[t]{2}{*}{ Replicase proteins $^{\circ}$} & For: GGGACAGCTTTCTTGTACAAAGTGGTAАССТТСТTСТАСАGGАССССААС & This study \\
\hline & Rev: GGGGACAACTTTGTATAATAAAGTTGTCATTGTATATAAАACTTGAAG & This study \\
\hline \multirow[t]{2}{*}{ Movement protein $^{\circ}$} & For: GGGGACAGCTTTCTTGTACAAAGTGGTAGCTCTGATGAAGAGGATAGC & This study \\
\hline & Rev: GGGGACAACTTTGTATAATAAAGTTGTCAAGGACCAGATCTTTGTTAC & This study \\
\hline \multirow{2}{*}{ Coat protein ${ }^{\circ}$} & For: GGGGACAGCTTTCTTGTACAAAGTGGTATCGATTCGTCAGGAGCTGAG & This study \\
\hline & Rev: GGGGACAACTTTGTATAATAAAGTTGTACATACTAAATGCACTCTC & This study \\
\hline \multicolumn{3}{|c|}{ (2010 } \\
\hline \multirow[t]{2}{*}{$N b D C L 4^{*}$} & For: TCTTTCGTACCCTGAGCAAC & This study \\
\hline & Rev: CACGCAACTCTGAATAGCCT & This study \\
\hline \multirow[t]{2}{*}{$N b A G O 1^{*}$} & For: TTCGTCCTACACAGATGGGA & This study \\
\hline & Rev: AGAAGCTGGCTCACAAAGTC & This study \\
\hline \multirow[t]{2}{*}{ NbAGO5 } & For: GGAAGAAATGGACGCAATCCGCAA & Odokonyero 2012 \\
\hline & Rev: ACAGGGAACAGACGTGTATGGTGT & Odokonyero 2012 \\
\hline \multirow[t]{2}{*}{ NbRDR6 } & For: AGTGATCTAGCAACCCAATGAG & Liu et al. 2012 \\
\hline & Rev: TTCAGGAATGTCTTCGAGCG & Liu et al. 2012 \\
\hline \multirow[t]{2}{*}{$N b P P 2 A$} & For: GACCCTGATGTTGATGTTCGCT & Liu et al. 2012 \\
\hline & Rev: GAGGGATTTGAAGAGAGATTTC & Liu et al. 2012 \\
\hline \multicolumn{3}{|c|}{ Green fluorescent protein (GFP)-messenger RNA quantification } \\
\hline \multirow[t]{2}{*}{$G F P$} & For: AGTGGAGAGGGTGAAGGTGATG & Ye et al. 2009 \\
\hline & Rev: TGATCTGGGTATCTTGAAAAGC & Ye et al. 2009 \\
\hline \multirow[t]{2}{*}{$N b F-b o x$} & For: GGCACTCACAAACGTCTATTTC & Liu et al. 2012 \\
\hline & Rev: ACCTGGGAGGCATCCTGCTTAT & Liu et al. 2012 \\
\hline \multicolumn{3}{|c|}{ GFP-derived small interfering RNA quantification } \\
\hline P2-GFP stem-loop primer & GTCGTATCCAGTGCAGGGTCCGAGGTATTCGCACTGGATACGACGCCGTT & This study \\
\hline P2-GFP qPCR forward & TTCCTGCCGACAAGCAAAAG & This study \\
\hline U6 stem-loop primer & GTGCAGGGTCCGAGGTTTTGGACCATTTCTCGAT & Turner et al. 2013 \\
\hline U6 qPCR forward & GGAACGATACAGAGAAGATTAGCA & Turner et al. 2013 \\
\hline Universal qPCR reverse & GTGCAGGGTCCGAGGT & Varkonyi-Gasic et al. 2007 \\
\hline
\end{tabular}

\begin{abstract}
LR recombination: attL $x$ AttR $\rightarrow$ AttB
\end{abstract}
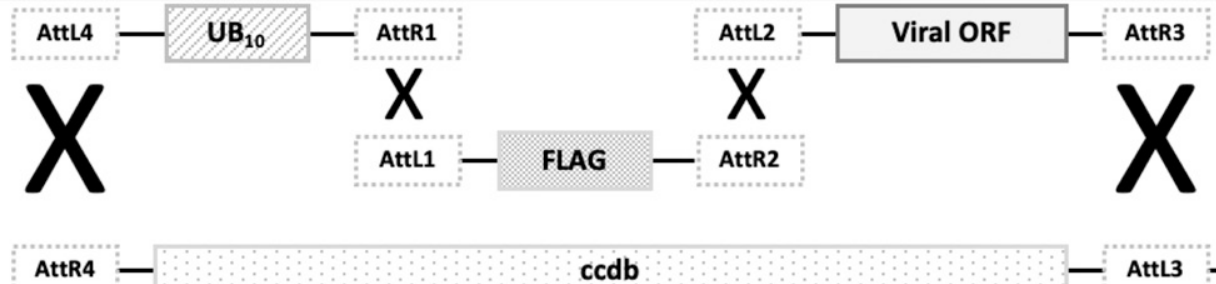

ccdb

AttL3

FLAG-tagged viral ORFs

\begin{tabular}{|c|c|c|c|c|}
\hline $\mathrm{UB}_{10}$ & FLAG & \multicolumn{3}{|c|}{ Replicase } \\
\hline $\mathrm{UB}_{10}$ & FLAG & Movement $\mathbf{P}$ & & T35S \\
\hline $\mathrm{UB}_{10}$ & FLAG & Coat Protein & T35 & \\
\hline
\end{tabular}

Fig. 6. Schematic representation of the construction of FLAG-tagged viral proteins encoded by grapevine Pinot gris virus and used in posttranscriptional gene-silencing suppression assays. Viral proteins were cloned and singularly fused with the FLAG epitope and UB10 constitutive promoter, using Multisite Gateway technology (Invitrogen). 
was evaluated with the BLASTN (nucleotide basic local alignment search tool [Altschul et al. 1997]) algorithm (Muller et al. 2002). Genes and primer sequences for expression analyses are reported in Table 1. A MNE for each gene of interest was calculated by normalizing their mean expression levels to the level of the NbPP2A gene. For each condition, three technical repeats and four individuals concurred with the gene MNE determinations. Statistical analyses of gene expression levels were performed with the StatPlus software package (AnalystSoft, StatPlus v7), using one-way ANOVA at a confidence level of $95 \%(P=0.05)$. Tukey's HSD post hoc test was used for pairwise comparisons.

\section{Quantification of GFP using fluorescence microscopy.}

Signal quantification of GFP was evaluated in silenced wt $N$. benthamiana plants and plants coinoculated with p35SGFP and either pP19, pGUS, pGPGV $\mathrm{REP}_{\text {, }} \mathrm{pGPV}_{\mathrm{MP}}$, or pGPGV $\mathrm{CP}_{\mathrm{CP}}$. The adaxial surface of four leaf samples per experimental condition was examined using a Zeiss Axio Observer Z1 epifluorescence microscope, using a 450- to 490-nm excitation filter and a 500-nm emission filter. Fluorescence signals were measured with the image analysis program Zen 2.3 (Blue Edition; Zeiss) on 20 random areas of $37.532 \mu \mathrm{m}^{2}$ each. The results were expressed as the mean \pm standard deviation. Data were collected from three independent experiments. Images were processed with ImageJ $1.49 \mathrm{~m}$ software package (National Institutes of Health).

\section{Quantification of GFP mRNA by real-time PCR.}

The expression level of GFP mRNA was determined in 16c $N$. benthamiana noninoculated and silenced plants as well as those coinoculated with $\mathrm{p} 35 \mathrm{~S}-\mathrm{GFP}$ and either pP19, pGUS, pGPGV $\mathrm{REP}_{\text {, }}$ $\mathrm{pGPGV}_{\mathrm{MP}}$, or $\mathrm{pGPGV} \mathrm{CP}_{\mathrm{CP}}$. The reference gene was individuated by comparing NbGAPDH, NbPP2A, NbF-box, and NbEF- $\alpha$ gene expression (Liu et al. 2012). The M values were calculated according to the geNorm program (Vandesompele et al. 2002) (Table 2). The F-box gene was found to be the most stably expressed gene in $N$. benthamania $16 \mathrm{c}$ plants and so the most suitable as a reference gene. Real-time experiments were performed on a CFX96 instrument (Bio-Rad Laboratories). SsoFast EvaGreen Supermix (Bio-Rad Laboratories Inc.), $5 \mathrm{ng}$ of cDNA, and GFP-specific primers (Ye et al. 2009) were used in a total volume of $15 \mu \mathrm{l}$. Every reaction was performed at $95^{\circ} \mathrm{C}$ for $3 \mathrm{~min}, 40$ cycles of $95^{\circ} \mathrm{C}$ for $5 \mathrm{~s}$ and $60^{\circ} \mathrm{C}$ for $5 \mathrm{~s}$, followed by a melting curve analysis from 65 to $95^{\circ} \mathrm{C}$ to check primer specificity. Primer sequences for quantification of GFP mRNA are listed in Table 1. An MNE for each gene of interest was calculated by normalizing its mean expression level to the level of the NbF-box gene. Three technical repeats and four individuals concurred with the gene MNE determination. The results were analyzed statistically with the StatPlus software package (AnalystSoft, StatPlus v7), using one-way ANOVA at a confidence level of $95 \%(P=0.05)$. Tukey's HSD post hoc test was used for pairwise comparisons.

Table 2. Validation of reference genes in the Nicotiana benthamiana wild type and $16 \mathrm{c}$ line

\begin{tabular}{lcr}
\hline & \multicolumn{2}{c}{ M value } \\
\cline { 2 - 3 } Gene $^{\mathbf{a}}$ & Wild type & 16c line \\
\hline$N b G A P D H$ & 0.1954 & 0.3258 \\
$N b P P 2 A$ & 0.1364 & 0.2053 \\
$N b F-b o x$ & 0.2137 & 0.2043 \\
$N b E F-\alpha$ & 0.2875 & 0.3090 \\
\hline${ }^{a}$ GAPDH $=$ glyceraldehyde-3-phosphate dehydrogenase, PP2A $=$ protein \\
phosphatase 2A, and $\alpha$-EF $=$ alpha elongation factor.
\end{tabular}

\section{Quantification of GFP-derived siRNAs by stem-loop RT-qPCR.}

The stem-loop, RT-qPCR approach was used for the quantification of siRNAs produced in a specific hotspot of the GFP transgene, referring to the protocol described by Christie et al. (2011). The procedure included two steps. First, a stem-loop RT primer was hybridized to a target siRNA molecule and it was then reverse transcribed via pulsed RT-PCR. Next, the RT product was quantified using qPCR. For the construction of stem-loop primer, the sequence of $\mathrm{P} 2$ probe reported by Christie et al. (2011) was assumed as being a representative target of the GFPderived siRNA population (P2-derived GFP siRNA). The P2 probe was chosen for its reliable and accurate ability to detect differences in GFP-derived siRNA densities in exons from intronless versus intron-containing GFP genes in Arabidopsis thaliana plants (Chen et al. 2005), resulting in a significant locus for siRNA biogenesis within the GFP transgene. The primer was designed according to Chen et al. $(2005,2011)$ and Varkonyi-Gasic et al. (2007) from nucleotide position 480 to 500 of the homologous mGFP5 sequence (accession number U87973.1), which was introduced into the transgenic $N$. benthamiana $16 \mathrm{c}$ line. The specificity of the stem-loop primer to P2-derived GFP siRNA was conferred by a six-nucleotide extension at the $3^{\prime}$ end, which is homologous to the reverse complement of the last six nucleotides at the $3^{\prime}$ end of the P2 sequence (De la Rosa and Reyes 2019; Lin and Lai 2013).

Pulsed RT-PCR was performed using the recombinant MMLVRT, as described here. One microgram of total RNA was incubated with $1.0 \mu \mathrm{l}$ of specific stem-loop primer $(1 \mu \mathrm{M})$ for $5 \mathrm{~min}$ at $70^{\circ} \mathrm{C}$. Samples were kept on ice for $3 \mathrm{~min}$. For the second phase of the reaction, $5 \mu \mathrm{l}$ of MMLV $5 \times$ reaction buffer, $2.5 \mathrm{mM}$ dNTPs, $25 \mathrm{U}$ of recombinant RNasin ribonuclease inhibitor (Promega), and $200 \mathrm{U}$ of MMLV RT enzyme were added to each sample. The second incubation consisted of $30 \mathrm{~min}$ at $16^{\circ} \mathrm{C}$, followed by a pulsed RT of 60 cycles at $30^{\circ} \mathrm{C}$ for $30 \mathrm{~s}, 42^{\circ} \mathrm{C}$ for $30 \mathrm{~s}$, and $50^{\circ} \mathrm{C}$ for $1 \mathrm{~s}$.

The U6 noncoding snRNA was used as the normalization control because it is a stable and commonly used reference for miRNA quantification (Turner et al. 2013). The sequence of the U6 stem-loop primer and the U6 forward primer used in qPCR were obtained from Varkonyi-Gasic et al. (2007).

The quantification of P2-derived GFP siRNA was performed via $\mathrm{qPCR}$, using the universal reverse primer reported by Chen et al. (2005) and sequence-specific forward primer. The P2-GFP forward primer was designed according to Varkonyi-Gasic et al. (2007) and was specific to the P2-derived GFP sequence, excluding the last six nucleotides at the $3^{\prime}$ end of the siRNA. A 5' extension of five random GC-rich nucleotides was added to the P2-GFP forward primer to increase the melting temperature (VarkonyiGasic et al. 2007). Construction of GFP stem-loop and forward primers is reported in Figure 7, while sequences are listed in Table 1. Real-time experiments were performed on a CFX96 instrument (Bio-Rad Laboratories). SsoFast EvaGreen Supermix (Bio-Rad Laboratories Inc.) was used to amplify $20 \mathrm{ng}$ of cDNA with sequence-specific forward primers and universal reverse primers in a total volume of $15 \mu \mathrm{l}$. Every reaction was performed at $95^{\circ} \mathrm{C}$ for $3 \mathrm{~min}, 40$ cycles of $95^{\circ} \mathrm{C}$ for $5 \mathrm{~s}$ and $60^{\circ} \mathrm{C}$ for $15 \mathrm{~s}$, followed by a melting curve analysis from 65 to $95^{\circ} \mathrm{C}$ to check primer specificity. An MNE for P2-derived GFP siRNA was calculated by normalizing its mean expression level to the level of the U6 snRNA (Muller et al. 2002). Three technical repeats and four individuals concurred with the MNE determination.

Data were statistically analyzed with the StatPlus software package (AnalystSoft, StatPlus v7), using one-way ANOVA at a confidence level of $95 \%(P=0.05)$. Tukey's HSD post hoc test was used for pairwise comparisons. 


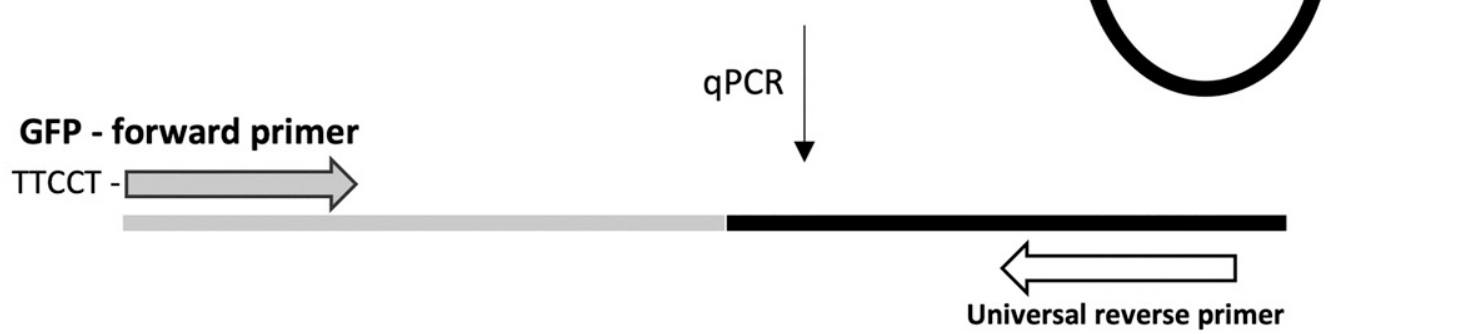

Fig. 7. Schematic representation of the construction of the stem-loop primer used in the pulsed reverse transcription PCR assay. The stem-loop sequence was based on sequences reported by Christie et al. (2011). The specific six-nucleotide extension at the $3^{\prime}$ end of the primer corresponded to the mGFP5-homologous sequence of the reverse complement of the six nucleotides at the $3^{\prime}$ end of P2 probe reported by Christie et al. (2011). The green fluorescent protein forward primer used in the quantitative PCR experiments was specific to the P2 probe sequence reported by Christie et al. (2011). A 5' extension of six nucleotides was added at the $5^{\prime}$ end of the primer to increase the melting temperature. The nucleotides were chosen randomly and are relatively rich in GC.

\section{ACKNOWLEDGMENTS}

The authors are sincerely grateful to O. Voinnet and all the members of RNA Biology Group at the Swiss Federal Institute of Technology (ETH, Zurich) for their valuable collaboration, constructive ideas, and critical advice in this project. In particular, many thanks to F. Brioudes, who kindly provided the plasmids, p35S-GFP, pUBI $10, \mathrm{p} 2 \times$ FLAG $2 \times \mathrm{HA}$, and pGUS used in this study and for his help during cloning experiments, A. Sarazin for in silico analyses, and G. Schott for his kind support in lab procedures. The authors are also grateful to L. Cantrill (Out of Site English, Sydney, Australia) for the English revision.

\section{AUTHOR-RECOMMENDED INTERNET RESOURCES}

FASTX Toolkit: http://hannonlab.cshl.edu/fastx_toolkit

Short Read Archive: https://trace.ncbi.nlm.nih.gov/Traces/sra/sra.cgi

\section{LITERATURE CITED}

Altschul, S. F., Madden, T. L., Schäffer, A. A., Zhang, J., Zhang, Z., Miller, W., and Lipman, D. J. 1997. Gapped BLAST and PSI-BLAST: A new generation of protein database search programs. Nucleic Acids Res. 25:3389-3402.

Amin, I., Hussain, K., Akbergenov, R., Yadav, J. S., Qazi, J., Mansoor, S., Hohn, T., Fauquet, C. M., and Briddon, R. W. 2011. Suppressors of RNA silencing encoded by the components of the cotton leaf curl begomovirus-betasatellite complex. Mol. Plant-Microbe Interact. 24:973-983.

Andika, I. B., Sun, L., Xiang, R., Li, J., and Chen, J. 2013. Root-specific role for Nicotiana benthamiana RDR6 in the inhibition of Chinese wheat mosaic virus accumulation at higher temperatures. Mol. Plant-Microbe Interact. 26:1165-1175

Axtell, M. J. 2017. Lost in translation? MicroRNAs at the rough ER. Trends Plant Sci. 22:273-274.

Azevedo, J., Garcia, D., Pontier, D., Ohnesorge, S., Yu, A., Garcia, S., Braun, L., Bergdoll, M., Hakimi, M. A., Lagrange, T., and Voinnet, O. 2010. Argonaute quenching and global changes in Dicer homeostasis caused by a pathogen-encoded GW repeat protein. Genes Dev. 24:904-915.

Baulcombe, D. C., and Molnár, A. 2004. Crystal structure of p19-A universal suppressor of RNA silencing. Trends Biochem. Sci. 29: 279-281.

Bernstein, E., Caudy, A. A., Hammond, S. M., and Hannon, G. J. 2001. Role for a bidentate ribonuclease in the initiation step of RNA interference. Nature 409:363-366.

Bertazzon, N., Forte, V., Filippin, L., Causin, R., Maixner, M., and Angelini, E. 2017. Association between genetic variability and titre of grapevine Pinot gris virus with disease symptoms. Plant Pathol. 66: 949-959.

Bianchi, G. L., De Amicis, F., De Sabbata, L., Di Bernardo, N., Governatori, G., Nonino, F., Prete, G., Marrazzo, T., Versolatto, S., and Frausin, C. 2015. Occurrence of grapevine Pinot gris virus in Friuli Venezia Giulia (Italy): Field monitoring and virus quantification by real-time RT-PCR. EPPO Bull. 45:22-32.

Bologna, N. G., and Voinnet, O. 2014. The diversity, biogenesis, and activities of endogenous silencing small RNAs in Arabidopsis. Annu. Rev. Plant Biol. 65:473-503.

Brodersen, P., Sakvarelidze-Achard, L., Schaller, H., Khafif, M., Schott, G., Bendahmane, A., and Voinnet, O. 2012. Isoprenoid biosynthesis is required for miRNA function and affects membrane association of ARGONAUTE 1 in Arabidopsis. Proc. Natl. Acad. Sci. U.S.A. 109: 1778-1783 
Brodersen, P., and Voinnet, O. 2006. The diversity of RNA silencing pathways in plants. Trends Genet. 22:268-280.

Brosseau, C., and Moffett, P. 2015. Functional and genetic analysis identify a role for Arabidopsis ARGONAUTE5 in antiviral RNA silencing. Plant Cell 27:1742-1754.

Buoso, S., Pagliari, L., Musetti, R., Fornasier, F., Martini, M., Loschi, A., Fontanella, M. C., and Ermacora, P. 2020. With or without you: Altered plant response to boron-deficiency in hydroponically grown grapevines infected by grapevine Pinot gris virus suggests a relation between grapevine leaf mottling and deformation symptom occurrence and boron plant availability. Front. Plant Sci. 11:226.

Carbonell, A., and Carrington, J. C. 2015. Antiviral roles of plant ARGONAUTES. Curr. Opin. Plant Biol. 27:111-117.

Chen, C., Ridzon, D. A., Broomer, A. J., Zhou, Z., Lee, D. H., Nguyen, J. T., Barbisin, M., Xu, N. L., Mahuvakar, V. R., Andersen, M. R. Lao, K. Q., Livak, K. J., and Guegler, K. J. 2005. Real-time quantification of microRNAs by stem-loop RT-PCR. Nucleic Acids Res. 33:e179.

Chen, C., Tan, R., Wong, L., Fekete, R., and Halsey, J. 2011. Quantitation of microRNAs by real-time RT-qPCR. Pages 113-134 in: PCR protocols. D. J. Park, ed. Humana Press, Totowa, NJ.

Cheng, A., Li, M., Liang, Y., Wang, Y., Wong, L., Chen, C., Vlassov, A. V., and Magdaleno, S. 2009. Stem-loop RT-PCR quantification of siRNAs in vitro and in vivo. Oligonucleotides 19:203-208.

Chiera, J. M., Lindbo, J. A., and Finer, J. J. 2008. Quantification and extension of transient GFP expression by the co-introduction of a suppressor of silencing. Transgenic Res. 17:1143-1154.

Chiu, M. H., Chen, I. H., Baulcombe, D. C., and Tsai, C. H. 2010. The silencing suppressor P25 of Potato virus $X$ interacts with Argonaute 1 and mediates its degradation through the proteasome pathway. Mol. Plant Pathol. 11:641-649.

Christie, M., Croft, L. J., and Carroll, B. J. 2011. Intron splicing suppresses RNA silencing in Arabidopsis. Plant J. 68:159-167.

Collum, T. D., Stone, A. L., Sherman, D. J., Rogers, E. E., Dardick, C., and Culver, J. N. 2020. Translatome profiling of Plum pox virus-infected leaves in European plum reveals temporal and spatial coordination of defense responses in phloem tissues. Mol. Plant-Microbe Interact. 33: 66-77.

Csorba, T., and Burgyán, J. 2016. Antiviral silencing and suppression of gene silencing in plants. Pages 1-33 in: Current research topics in plant virology. Wang, A., and Zhou, X., eds. Springer International Publishing, Cham.

Cuellar, W. J., Kreuze, J. F., Rajamäki, M.-L., Cruzado, K. R., Untiveros, M., and Valkonen, J. P. T. 2009. Elimination of antiviral defense by viral RNase III. Proc. Natl. Acad. Sci. U.S.A. 106:10354-10358.

Czech, B., and Hannon, G. J. 2011. Small RNA sorting: Matchmaking for Argonautes. Nat. Rev. Genet. 12:19-31.

Czimmerer, Z., Hulvely, J., Simandi, Z., Varallyay, E., Havelda, Z., Szabo, E., Varga, A., Dezso, B., Balogh, M., Horvath, A., Domokos, B., Torok, Z., Nagy, L., and Balint, B. L. 2013. A versatile method to design stemloop primer-based quantitative PCR assays for detecting small regulatory RNA molecules. PLoS One 8:e55168.

Czotter, N., Molnar, J., Szabó, E., Demian, E., Kontra, L., Baksa, I., Szittya, G., Kocsis, L., Deak, T., Bisztray, G., Tusnady, G. E., Burgyan, J., and Varallyay, E. 2018. NGS of virus-derived small RNAs as a diagnostic method used to determine viromes of Hungarian vineyards. Front. Microbiol. 9:122.

De la Rosa, C., and Reyes, J. L. 2019. Northern blot analysis of microRNAs and other small RNAs in plants. Pages 121-129 in: Plant microRNAs. S. de Folter, ed. Springer New York, New York.

Deleris, A., Gallego-Bartolome, J., Bao, J., Kasschau, K. D., Carrington, J. C., and Voinnet, O. 2006. Hierarchical action and inhibition of plant Dicer-like proteins in antiviral defense. Science 313:68-71.

Devers, E. A., Brosnan, C. A., Sarazin, A., Albertini, D., Amsler, A. C., Brioudes, F., Jullien, P. E., Lim, P., Schott, G., and Voinnet, O. 2020. Movement and differential consumption of short interfering RNA duplexes underlie mobile RNA interference. Nat. Plants 6:789799.

Ding, S.-W., and Voinnet, O. 2007. Antiviral immunity directed by small RNAs. Cell 130:413-426.

Duan, C.-G., Fang, Y.-Y., Zhou, B.-J., Zhao, J.-H., Hou, W.-N., Zhu, H., Ding, S.-W., and Guo, H.-S. 2012. Suppression of Arabidopsis ARGONAUTE1-mediated slicing, transgene-induced RNA silencing, and DNA methylation by distinct domains of the Cucumber mosaic virus 2b protein. Plant Cell 24:259-274.

Dunoyer, P., Himber, C., and Voinnet, O. 2005. DICER-LIKE 4 is required for RNA interference and produces the 21-nucleotide small interfering RNA component of the plant cell-to-cell silencing signal. Nat. Genet. 37:1356-1360.
Fire, A. 1999. RNA-triggered gene silencing. Trends Genet. 15:358-363.

Garcia-Ruiz, H., Carbonell, A., Hoyer, J. S., Fahlgren, N., Gilbert, K. B., Takeda, A., Giampetruzzi, A., Garcia Ruiz, M. T., McGinn, M. G., Lowery, N., Martinez Baladejo, M. T., and Carrington, J. C. 2015. Roles and programming of Arabidopsis ARGONAUTE proteins during Turnip mosaic virus infection. PLoS Pathog. 11:e1004755.

Ghoshal, B., and Sanfaçon, H. 2015. Symptom recovery in virus-infected plants: Revisiting the role of RNA silencing mechanisms. Virology 479-480:167-179.

Giampetruzzi, A., Roumi, V., Roberto, R., Malossini, U., Yoshikawa, N., La Notte, P., Terlizzi, F., Credi, R., and Saldarelli, P. 2012. A new grapevine virus discovered by deep sequencing of virus- and viroid-derived small RNAs in Cv Pinot gris. Virus Res. 163:262-268.

Guo, H., Song, X., Xie, C., Huo, Y., Zhang, F., Chen, X., Geng, Y., and Fang, R. 2013. Rice yellow stunt rhabdovirus protein 6 suppresses systemic RNA silencing by blocking RDR6-mediated secondary siRNA synthesis. Mol. Plant-Microbe Interact. 26:927-936.

Guo, H. S., and Ding, S. W. 2002. A viral protein inhibits the long range signaling activity of the gene silencing signal. EMBO J. 21:398-407.

Haseloff, J., Siemering, K. R., Prasher, D. C., and Hodge, S. 1997. Removal of a cryptic intron and subcellular localization of green fluorescent protein are required to mark transgenic Arabidopsis plants brightly. Proc. Natl. Acad. Sci. U.S.A. 94:2122-2127.

Henderson, I. R., Zhang, X., Lu, C., Johnson, L., Meyers, B. C., Green, P. J., and Jacobsen, S. E. 2006. Dissecting Arabidopsis thaliana DICER function in small RNA processing, gene silencing and DNA methylation patterning. Nat. Genet. 38:721-725.

Hily, J.-M., Poulicard, N., Candresse, T., Vigne, E., Beuve, M., Renault, L., Velt, A., Spilmont, A.-S., and Lemaire, O. 2019. Datamining, genetic diversity analyses and phylogeographic reconstructions redefine the worldwide evolutionary history of grapevine Pinot gris virus and grapevine berry inner necrosis virus. Phytobiomes J. 4:165-177.

Himber, C., Dunoyer, P., Moissiard, G., Ritzenthaler, C., and Voinnet, O. 2003. Transitivity-dependent and -independent cell-to-cell movement of RNA silencing. EMBO J. 22:4523-4533.

Iki, T., Tschopp, M.-A., and Voinnet, O. 2017. Biochemical and genetic functional dissection of the P38 viral suppressor of RNA silencing. RNA 23:639-654.

Kalantidis, K., Tsagris, M., and Tabler, M. 2006. Spontaneous short-range silencing of a GFP transgene in Nicotiana benthamiana is possibly mediated by small quantities of siRNA that do not trigger systemic silencing. Plant J. 45:1006-1016.

Karimi, M., De Meyer, B., and Hilson, P. 2005. Modular cloning in plant cells. Trends Plant Sci. 10:103-105.

Keller, M. 2015. The Science of Grapevines: Anatomy and Physiology. 2nd edition. Elsevier Academic Press, Amsterdam.

Kim, Y. J., Maizel, A., and Chen, X. 2014. Traffic into silence: Endomembranes and post-transcriptional RNA silencing. EMBO J. 33: 968-980.

Kørner, C. J., Pitzalis, N., Peña, E. J., Erhardt, M., Vazquez, F., and Heinlein, M. 2018. Crosstalk between PTGS and TGS pathways in natural antiviral immunity and disease recovery. Nat. Plants 4: $157-164$.

Kramer, M. F. 2011. Stem-loop RT-qPCR for miRNAs. Curr. Protoc. Mol. Biol. Chapter 15:15.10.

Križnik, M., Baebler, S., and Gruden, K. 2020. Roles of small RNAs in the establishment of tolerant interaction between plants and viruses. Curr. Opin. Virol. 42:25-31.

Laird, J., McInally, C., Carr, C., Doddiah, S., Yates, G., Chrysanthou, E., Khattab, A., Love, A. J., Geri, C., Sadanandom, A., Smith, B. O., Kobayashi, K., and Milner, J. J. 2013. Identification of the domains of cauliflower mosaic virus protein P6 responsible for suppression of RNA silencing and salicylic acid signalling. J. Gen. Virol. 94:27772789

Lanet, E., Delannoy, E., Sormani, R., Floris, M., Brodersen, P., Crété, P., Voinnet, O., and Robaglia, C. 2009. Biochemical evidence for translational repression by Arabidopsis microRNAs. Plant Cell 21:17621768.

Langmead, B., and Salzberg, S. L. 2012. Fast gapped-read alignment with Bowtie 2. Nat. Methods 9:357-359.

Li, S., Liu, L., Zhuang, X., Yu, Y., Liu, X., Cui, X., Ji, L., Pan, Z., Cao, X., Mo, B., Zhang, F., Raikhel, N., Jiang, L., and Chen, X. 2013. MicroRNAs inhibit the translation of target mRNAs on the endoplasmic reticulum in Arabidopsis. Cell 153:562-574.

Lin, Y. L., and Lai, Z. X. 2013. Evaluation of suitable reference genes for normalization of microRNA expression by real-time reverse transcription PCR analysis during longan somatic embryogenesis. Plant Physiol. Biochem. 66:20-25. 
Liu, D., Shi, L., Han, C., Yu, J., Li, D., and Zhang, Y. 2012. Validation of reference genes for gene expression studies in virus-infected Nicotiana benthamiana using quantitative real-time PCR. PLoS One 7: e46451.

Liu, Q., Feng, Y., and Zhu, Z. 2009. Dicer-like (DCL) proteins in plants Funct. Integr. Genomics 9:277-286.

Marchais, A., Chevalier, C., and Voinnet, O. 2019. Extensive profiling in Arabidopsis reveals abundant polysome-associated 24-nt small RNAs including AGO5-dependent pseudogene-derived siRNAs. RNA 25: 1098-1117.

Marcial-Quino, J., Gómez-Manzo, S., Fierro, F., Vanoye-Carlo, A., Rufino-González, Y., Sierra-Palacios, E., Castillo-Villanueva, A., Castillo-Rodríguez, R. A., Rodríguez-Bustamante, E., ArreguinEspinosa, R., and Reyes-Vivas, H. 2016. Stem-loop RT-qPCR as an efficient tool for the detection and quantification of small RNAs in Giardia lamblia. Genes (Basel) 7:131.

Martelli, G. P. 2017. An overview on grapevine viruses, viroids, and the diseases they cause. Pages 31-46 in: Grapevine Viruses: Molecular Biology, Diagnostics and Management. B. Meng, G. P. Martelli, D. A. Golino, and M. Fuchs, eds. Springer International Publishing, Cham, Switzerland.

Meister, G., and Tuschl, T. 2004. Mechanisms of gene silencing by doublestranded RNA. Nature 431:343-349.

Meng, B., Martelli, G. P., Golino, D. A., and Fuchs, M., eds. 2017. Grapevine Viruses: Molecular Biology, Diagnostics and Management. Springer International Publishing, Cham, Switzerland.

Mi, S., Cai, T., Hu, Y., Chen, Y., Hodges, E., Ni, F., Wu, L., Li, S., Zhou, H., Long, C., Chen, S., Hannon, G. J., and Qi, Y. 2008. Sorting of small RNAs into Arabidopsis Argonaute complexes is directed by the $5^{\prime}$ terminal nucleotide. Cell 133:116-127.

Michaeli, S., Clavel, M., Lechner, E., Viotti, C., Wu, J., Dubois, M., Hacquard, T., Derrien, B., Izquierdo, E., Lecorbeiller, M., Bouteiller, N., De Cilia, J., Ziegler-Graff, V., Vaucheret, H., Galili, G., and Genschik, P. 2019. The viral F-box protein P0 induces an ER-derived autophagy degradation pathway for the clearance of membrane-bound AGO1. Proc. Natl. Acad. Sci. U.S.A. 116:22872-22883.

Moissiard, G., and Voinnet, O. 2004. Viral suppression of RNA silencing in plants. Mol. Plant Pathol. 5:71-82.

Muller, P.Y., Miserez, A. R., and Dobbie, Z. 2002. Processing of gene expression data generated by quantitative real-time RT-PCR. Biotechniques 32:1372-1374, 1376, 1378-1379.

Odokonyero, D. 2012. Identification of argonautes involved in antiviral RNA silencing in Nicotiana benthamiana. PhD. dissertation. Texas A\&M University, College Station, TX, U.S.A

Oliver, J. E., and Fuchs, M. 2011. Tolerance and resistance to viruses and their vectors in Vitis sp.: A virologist's perspective of the literature. Am. J. Enol. Vitic. 62:438-451.

Parent, J.-S., Bouteiller, N., Elmayan, T., and Vaucheret, H. 2015. Respective contributions of Arabidopsis DCL2 and DCL4 to RNA silencing. Plant J. 81:223-232.

Pumplin, N., and Voinnet, O. 2013. RNA silencing suppression by plant pathogens: Defence, counter-defence and counter-counter-defence. Nat. Rev. Microbiol. 11:745-760.

Qin, C., Li, B., Fan, Y., Zhang, X., Yu, Z., Ryabov, E., Zhao, M., Wang, H., Shi, N., Zhang, P., Jackson, S., Tör, M., Cheng, Q., Liu, Y., Gallusci, P., and Hong, Y. 2017. Roles of Dicer-like proteins 2 and 4 in intra- and intercellular antiviral silencing. Plant Physiol. 174:1067-1081.

Qu, F. 2010. Antiviral role of plant-encoded RNA-dependent RNA polymerases revisited with deep sequencing of small interfering RNAs of virus origin. Mol. Plant-Microbe Interact. 23:1248-1252.

Ratcliff, F. G., MacFarlane, S. A., and Baulcombe, D. C. 1999. Gene silencing without DNA. RNA-mediated cross-protection between viruses. Plant Cell 11:1207-1215.

Raymond, C. K., Roberts, B. S., Garrett-Engele, P., Lim, L. P., and Johnson, J. M. 2005. Simple, quantitative primer-extension PCR assay for direct monitoring of microRNAs and short-interfering RNAs. RNA 11:1737-1744.

Reynoso, M. A., Blanco, F. A., Bailey-Serres, J., Crespi, M., and Zanetti, M. E. 2013. Selective recruitment of mRNAs and miRNAs to polyribosomes in response to rhizobia infection in Medicago truncatula. Plant $\mathrm{J}$. 73:289-301

Romero-Brey, I., and Bartenschlager, R. 2016. Endoplasmic reticulum: The favorite intracellular niche for viral replication and assembly. Viruses 8: 160.

Roussin-Léveillée, C., Silva-Martins, G., and Moffett, P. 2019. Argonaute 5 mediates fine-tuning of vegetative-to-reproductive phase transition through its interaction with miR156 in Arabidopsis. bioRxiv 640680.
Ruiz, M. T., Voinnet, O., and Baulcombe, D. C. 1998. Initiation and maintenance of virus-induced gene silencing. Plant Cell 10:937-946.

Saldarelli, P., Giampetruzzi, A., Morelli, M., Malossini, U., Pirolo, C., Bianchedi, P., and Gualandri, V. 2015. Genetic variability of grapevine Pinot gris virus and its association with grapevine leaf mottling and deformation. Phytopathology 105:555-563.

Schaad, M. C., Jensen, P. E., and Carrington, J. C. 1997. Formation of plant RNA virus replication complexes on membranes: Role of an endoplasmic reticulum-targeted viral protein. EMBO J. 16:4049-4059.

Schuck, J., Gursinsky, T., Pantaleo, V., Burgyán, J., and Behrens, S.-E. 2013. AGO/RISC-mediated antiviral RNA silencing in a plant in vitro system. Nucleic Acids Res. 41:5090-5103.

Senda, M., Masuta, C., Ohnishi, S., Goto, K., Kasai, A., Sano, T., Hong, J. S., and MacFarlane, S. 2004. Patterning of virus-infected Glycine max seed coat is associated with suppression of endogenous silencing of chalcone synthase genes. Plant Cell 16:807-818.

Sharbati-Tehrani, S., Kutz-Lohroff, B., Bergbauer, R., Scholven, J., and Einspanier, R. 2008. miR-Q: A novel quantitative RT-PCR approach for the expression profiling of small RNA molecules such as miRNAs in a complex sample. BMC Mol. Biol. 9:34.

Shi, R., and Chiang, V. L. 2005. Facile means for quantifying microRNA expression by real-time PCR. Biotechniques 39:519-525.

Smith, N. A., Eamens, A. L., and Wang, M.-B. 2011. Viral small interfering RNAs target host genes to mediate disease symptoms in plants. PLoS Pathog. 7:e1002022.

Smoczynska, A., Sega, P., Stepien, A., Knop, K., Jarmolowski, A., Pacak, A., and Szweykowska-Kulinska, Z. 2019. miRNA detection by stemloop RT-qPCR in studying microRNA biogenesis and microRNA responsiveness to abiotic stresses. Methods Mol. Biol. 1932:131-150.

Stalder, L., Heusermann, W., Sokol, L., Trojer, D., Wirz, J., Hean, J., Fritzsche, A., Aeschimann, F., Pfanzagl, V., Basselet, P., Weiler, J., Hintersteiner, M., Morrissey, D. V., and Meisner-Kober, N. C. 2013. The rough endoplasmatic reticulum is a central nucleation site of siRNA-mediated RNA silencing. EMBO J. 32:1115-1127.

Szittya, G., and Burgyán, J. 2013. RNA interference-mediated intrinsic antiviral immunity in plants. Vol. 371. Pages 153-181 in: Intrinsic Immunity. B. Cullen, ed. Springer, Berlin.

Takeda, A., Iwasaki, S., Watanabe, T., Utsumi, M., and Watanabe, Y. 2008 The mechanism selecting the guide strand from small RNA duplexes is different among argonaute proteins. Plant Cell Physiol. 49:493-500.

Tarquini, G., De Amicis, F., Martini, M., Ermacora, P., Loi, N., Musetti, R., Bianchi, G. L., and Firrao, G. 2019a. Analysis of new grapevine Pinot gris virus (GPGV) isolates from Northeast Italy provides clues to track the evolution of a newly emerging clade. Arch. Virol. 164:1655-1660.

Tarquini, G., Ermacora, P., Bianchi, G. L., De Amicis, F., Pagliari, L., Martini, M., Loschi, A., Saldarelli, P., Loi, N., and Musetti, R. 2018. Localization and subcellular association of Grapevine Pinot Gris Virus in grapevine leaf tissues. Protoplasma 255:923-935.

Tarquini, G., Zaina, G., Ermacora, P., De Amicis, F., Franco-Orozco, B., Loi, N., Martini, M., Bianchi, G. L., Pagliari, L., Firrao, G., de Paoli, E., and Musetti, R. 2019b. Agroinoculation of Grapevine Pinot Gris Virus in tobacco and grapevine provides insights on viral pathogenesis. PLoS One 14:e0214010.

Turner, M., Adhikari, S., and Subramanian, S. 2013. Optimizing stem-loop qPCR assays through multiplexed cDNA synthesis of U6 and miRNAs. Plant Signal. Behav. 8:e24918.

Van Ex, F., Jacob, Y., and Martienssen, R. A. 2011. Multiple roles for small RNAs during plant reproduction. Curr. Opin. Plant Biol. 14:588-593.

Vandesompele, J., De Preter, K., Pattyn, F., Poppe, B., Van Roy, N., De Paepe, A., and Speleman, F. 2002. Accurate normalization of real-time quantitative RT-PCR data by geometric averaging of multiple internal control genes. Genome Biol. 3:research0034-1.

Varkonyi-Gasic, E., Wu, R., Wood, M., Walton, E. F., and Hellens, R. P. 2007. Protocol: A highly sensitive RT-PCR method for detection and quantification of microRNAs. Plant Methods 3:12.

Voinnet, O. 2001. RNA silencing as a plant immune system against viruses. Trends Genet. 17:449-459.

Voinnet, O. 2005. Induction and suppression of RNA silencing: Insights from viral infections. Nat. rev. Genet. 6:206-220.

Voinnet, O. 2008. Post-transcriptional RNA silencing in plant-microbe interactions: A touch of robustness and versatility. Curr. Opin. Plant Biol. 11:464-470.

Voinnet, O. 2009. Origin, biogenesis, and activity of plant microRNAs. Cell 136:669-687.

Voinnet, O., Pinto, Y. M., and Baulcombe, D. C. 1999. Suppression of gene silencing: A general strategy used by diverse DNA and RNA viruses of plants. Proc. Natl. Acad. Sci. U.S.A. 96:14147-14152. 
Wang, X.-B., Wu, Q., Ito, T., Cillo, F., Li, W.-X., Chen, X., Yu, J.-L., and Ding, S.-W. 2010. RNAi-mediated viral immunity requires amplification of virus-derived siRNAs in Arabidopsis thaliana. Proc. Natl. Acad. Sci. U.S.A. 107:484-489.

Waterhouse, P. M., Wang, M. B., and Lough, T. 2001. Gene silencing as an adaptive defence against viruses. Nature 411:834-842.

Yang, L. H., Wang, S. L., Tang, L. L., Liu, B., Ye, W. L., Wang, L. L., Wang, Z. Y., Zhou, M. T., and Chen, B. C. 2014. Universal stem-loop primer method for screening and quantification of microRNA. PLoS One 9:e115293.

Yang, Z., and Li, Y. 2018. Dissection of RNAi-based antiviral immunity in plants. Curr. Opin. Virol. 32:88-99.

Ye, J., Qu, J., Zhang, J.-F., Geng, Y.-F., and Fang, R.-X. 2009. A critical domain of the Cucumber mosaic virus $2 b$ protein for RNA silencing suppressor activity. FEBS Lett. 583:101-106.
Ye, K., Malinina, L., and Patel, D. J. 2003. Recognition of small interfering RNA by a viral suppressor of RNA silencing. Nature 426:874-878.

Zhang, C., Chen, D., Yang, G., Yu, X., and Wu, J. 2020. Rice stripe mosaic virus-encoded P4 is a weak suppressor of viral RNA silencing and is required for disease symptom development. Mol. Plant-Microbe Interact. 33:412-422.

Zhang, X., Yuan, Y.-R., Pei, Y., Lin, S.-S., Tuschl, T., Patel, D. J., and Chua, N.-H. 2006. Cucumber mosaic virus-encoded 2b suppressor inhibits Arabidopsis Argonaute1 cleavage activity to counter plant defense. Genes Dev. 20:3255-3268.

Zhang, X., Zhang, X., Singh, J., Li, D., and Qu, F. 2012. Temperaturedependent survival of Turnip crinkle virus-infected Arabidopsis plants relies on an RNA silencing-based defense that requires dc12, AGO2, and HEN1. J. Virol. 86:6847-6854. 